\title{
Examining Ali Kayımzade House and Sevilay Pașazade House as examples of Traditional Houses in Lefke
}

\author{
Ali Kayımzade Evi ve Sevilay Paşazade Evi'ni Lefke'deki \\ Geleneksel Ev Örnekleri Olarak İrdelemek
}

D Makbule OKTAY

Traditional buildings that are evaluated as cultural heritage sites are built by locals using available materials, simple tools, and existing technology by considering the cultural and environmental characteristics of a particular region. These structures form a bond between past, present, and future, conveying valuable information to future generations. Lefke, located in the north-west of Cyprus, is one of the settlements where various structures of different cultures that intertwined over time can be seen as the city comprises the multicultural traces of Cyprus . Examples of residential architecture from the Ottoman and British periods that have been built in the Ottoman style are an important part of the traditional urban texture of Lefke. This article aims to examine two traditional houses in Lefke that have Ottoman house characteristics. Therefore, building plot - building relationships, plan typology, spatial use, façade features, building materials, and construction techniques have been inspected and documented. By doing so, it is aimed to contribute to traditional architecture and cultural heritage studies.

Keywords: Cultural heritage; Lefke; Ottoman architecture; traditional house; traditional urban texture.

Geleneksel yapılar, yerli halk tarafından yerel malzemelerle, basit aletler ve mevcut teknoloji kullanılarak, belirli bir bölgenin kültürel ve çevresel özellikleri dikkate alınarak inşa edilmiş yapılardır. Bu yapılar geçmiş, şimdiki zaman ve gelecek arasında bağ oluşturmakta ve gelecek nesillere bilgi aktarmaktadır. Kıbrıs'ın kuzey batısında bulunan Lefke, farklı kültürlere ait yapıların iç içe geçmiş bir şekilde görülebileceği yerleşimlerden biri olup Kıbrıs'ın çok kültürlü izlerini taşıyan birçok yapıyı bünyesinde barındırmaktadır. Bu yapılardan, Osmanlı dönemi sivil mimari örnekleri bölgenin geleneksel kent dokusunun önemli bir parçasıdır. Bu araştırmada, Lefke geleneksel kent dokusunun bir parçası olan Osmanlı sivil mimari örneklerinden -geleneksel Lefke evlerinden-iki örneğin arsa-yapı ilişkisinin, plan tipolojisinin, mekân kullanımının, cephe özelliklerinin, yapı malzemelerinin ve yapım tekniklerinin incelenmesi, belgelenmesi ve böylece geleneksel mimari ve kültürel miras çalışmalarına katkı sağlanması amaçlanmıştır.

Anahtar sözcükler: Kültürel miras; Lefke; Osmanlı mimarisi; geleneksel konut; geleneksel kent dokusu. 


\section{Introduction}

Historic buildings have architectural values that reflect the history of the settlements and the culture and socioeconomic status of societies. Besides their architectural value, they bear aesthetic, historic, documentary, archaeological, economic, social, political, spiritual or symbolic and emotional values (Feilden, 1994, p.1.). However, the number of these buildings are decreasing due to "contemporary urbanization problems, lack of maintenance, material deterioration, natural disasters and new developments" (Ahunbay, 2011, p.28), political events, wars, governmental policies, ownership problems, economic situation of individuals and/or societies. Despite all these negative factors, the preservation of historic environments and historic structures is important since they are "historic documents", "social and economic documents", "technical documents" and "aesthetic documents" (Kuban, 2000, p.61), and "symbols of our cultural identity and continuity - a part of our heritage" (Feilden, 1994, p.1).

Historic buildings constitute the architectural identity of a place. The architectural identity of any region is described through the architectural style, spatial organisation, construction technique, and the quality of the decorations of the buildings in historic settings and evaluated as historic data (Ahunbay, 2011, p.116). The examples of traditional residential architecture are considered as historic data since their formation and organisation are shaped in a way that reveals the cultural environment that they were situated in (Rapoport, 1969). They are the smallest units of architecture reflecting the history and culture; lifestyle, economic structure, traditions, customs, religion, and beliefs of the societies that they evolved in.

Preservation of traditional houses is compulsory since not making an effort to conserve these traditional harmonies, which constitute the core of human existence on earth, would be an act incompatible with human heritage (International Council on Monuments and Sites). The loss of a traditional house is a loss of an architectural, aesthetic, historic, and social document (Kuban, 2000, p.149). Considering all these, it is obliged not only to preserve but study, document and learn from traditional environments and buildings. By doing so, it will be possible to enjoy and get benefit from them at the present time and also transfer them for the benefit of the future.

In this context, the present study aims to examine the examples from the traditional houses of Lefke that have the characteristics of an Ottoman House and are part of the traditional urban texture. Lefke is a town located in the north-west of Cyprus which was part of the Ottoman Empire between 1571 and 1878 (Figure 1). Similar to the other towns of Cyprus, the traces of Ottoman lifestyle and

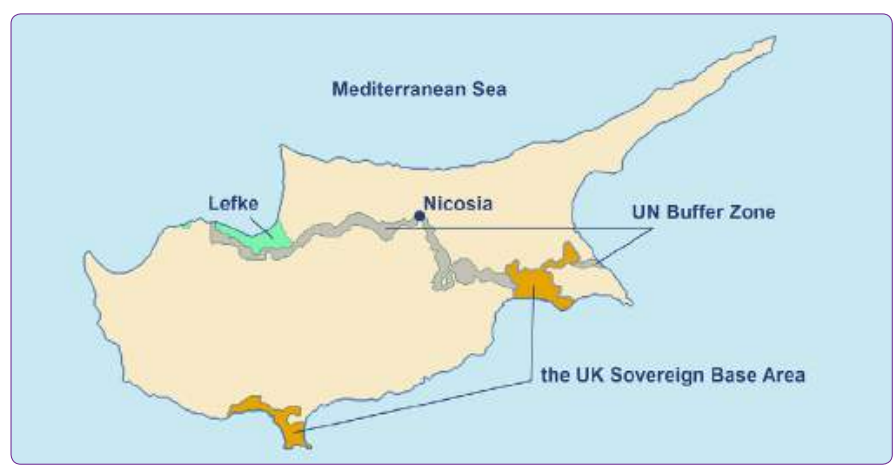

Figure 1. Location of Lefke. Source: Makbule Oktay, April 2019.

architecture can be read through the built environment of Lefke.

Many studies in the literature discuss the terminologies of 'Turkish House', 'Ottoman House', and 'Anatolian House' depending on ethnicity, plan types, regional differences, building material, and construction techniques (Asatekin, 2005; Bektaş, 2007; Eldem, 1954; Güçhan, 2018; Küçükerman, 1996; Tuztaşı \& Aşkun, 2013; Türeli, 2014). It is not the scope of this study to discuss these terminologies, yet it should be clarified that 'Ottoman House' is the term used locally in Lefke to refer to the two-storey houses with projecting bay, which were built in the Ottoman Period and the following British Period (1878-1960).

There are 10 two-storey houses with projecting bay in the town centre of Lefke. Four of these are located on the Fadıl Nekipzade Street, which was once one of the main arteries of the town and is known by the existence of these two-storey traditional houses with projecting bay. The selection criteria for the houses in this paper are types of users, frequency of use, ease of access and documentation. The aim was to study the houses which are possessed by their current inhabitants who are the descendants of the first owners. Another selection criterion is frequency of use. The houses which are used either constantly or rarely were selected. Inaccessibility to the traditional houses in Lefke is one of the obstacles that prevent them from being studied, as they are either abandoned, not in regular use or used by tenants. Thus, houses which are accessible were selected. Consequently, Ali Kayımzade House, which is the only two-storey traditional house with a projecting bay located on the east of the street and Sevilay Paşazade House, which is the one in constant use from two houses located on the west of the street, were selected as the case houses to be surveyed in this study (Figure 2).

Although these houses are the symbols of the town and part of its identity, there are limited studies related to them. Within the scope of the study, a field study was carried out and the architectural characteristics and spatial use of the selected houses were documented. Interviews were conducted with the owners of the houses, 


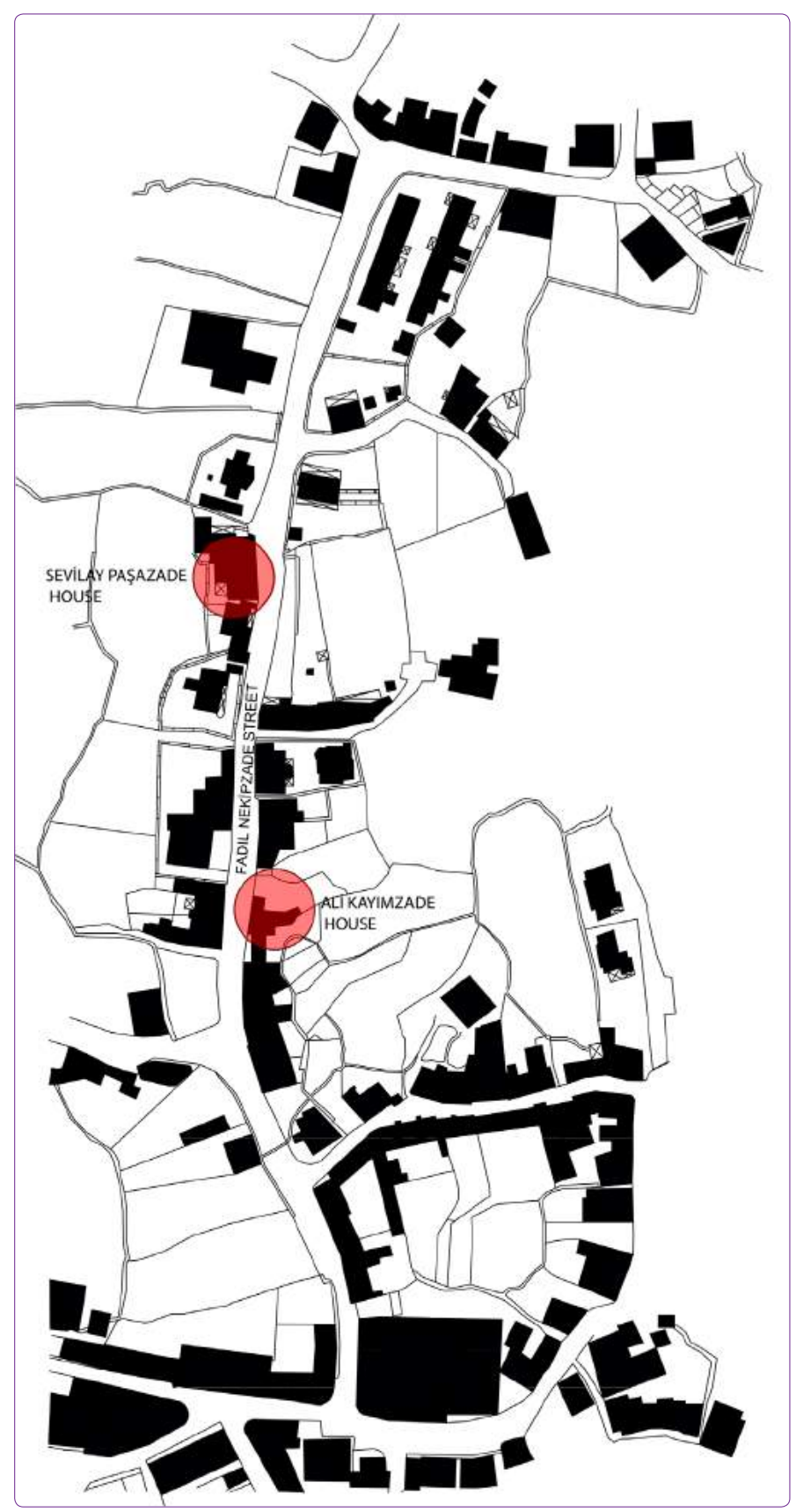

Figure 2. Fadıl Nekipzade Street and locations of Ali Kayımzade house and Sevilay Paşazade house on the street. Source: Makbule Oktay, May 2019.

the houses were surveyed in detail, measured drawings were prepared and photographs were taken during the field study. The building plot and building relationships, the plan typology and the spatial use, the façade features and building materials, and construction techniques are deeply analysed and presented. By doing so, it is aimed to understand the plan and façade formation of these houses, to document the characteristics of traditional houses, and also to contribute to the cultural heritage and heritage protection studies.

\section{Historical Background and Geographical Characteristics of Lefke}

Cyprus has been the centre of attention of many civilizations throughout its history due to its strategic location and therefore, has experienced the administration of many rulers. The most recent rulers are Lusignans (1192-1489), Venetians (1489-1571), Ottomans (15711878), and British (1878-1960) (Gunnis, 1973; Gürkan, 2008; Keshishian, 1993). In 1960 the Republic of Cyprus was founded by Greek Cypriots and Turkish Cypriots which lasted for three years. As a result of the conflict and war between these communities, the island was divided into two parts, where Turkish Cypriots settled to the north and Greek Cypriots to the southern part of the island.

Lefke is one of the settlements where the buildings, considered as traces of these different cultures, can be seen as intertwined and they form the settlement pattern of the region. It is situated on the northern slopes of the Troodos Mountains and is located in a valley $3.5 \mathrm{~km}$ away from the coast. Two streams run on both sides of the town; Gemikonağ stream from the west and Lefke stream from the east. The town covers an area of 8 square kilometres and is divided into 14 regions; Acendu, Alçı Dağı, Aplıç, Armutlular, Aşağı Camii, Çarşı, Esentepe, Eski Karadağ, Harmanlar, Karşıyaka, Memeler Dağı, Pir Paşa Camii, Tepe, and Yeni Karadağ (Ferlison, 1986, p.2).

The oldest remains in the town belong to the Byzantine period (Öztek, 1989, p.1). During the middle ages, Lefke was one of the chief baronies of Cyprus (Gunnis, 1973, p.320). It was a district centre during the Lusignan and Venetian periods (Bağışkan, 2018, p.210). When the Ottomans took the administration in 1571 the island was divided into districts and Lefke became one of the 16 districts (Hill, 2016; Öztek, 1989).

Cyprus was leased to the British in 1878 and became a British colony in 1925 until the Republic of Cyprus was founded in 1960. The copper mine in Lefke which was operated during the Roman period (Gunnis, 1973, p.320) was opened to be re-operated by an American company called the Cyprus Mines Corporation (CMC) in 1915 during British rule (Öztek, 1989, p.1). The company suspended its activities between 1939 and 1945 under the influence of World War II and closed down in 1974 (Feridun, 1976, pp.39-42).

All these changes had an impact on the population of Lefke. From the 16th century onwards, the majority of the population in the town was constituted by the Turks which is followed by Greeks and Armenians (Beratlı, 2002, pp.23-25). According to Ottoman data of $1831,90 \%$ of the population were Muslims (PRIO Cyprus Centre, n.d.) and there was a small Greek Cypriot community until 1960. Lefke's population increased during the periods when the 
mine was active and decreased when the mine was closed and people who used to work at CMC started to migrate (Feridun, 1976, p.42; PRIO Cyprus Centre, n.d.). In 1973 the population was 4544 Turkish Cypriots, while it decreased drastically to 1882 in 1978 (PRIO Cyprus Centre, n.d.).

After 1974, Lefke became a dead-end in the north. It lost its role as a regional centre (Öztek, 1989, p.2). According to the 2011 census, the population was 3009 . The border in Lefke was opened on 12 November 2018 and crossing point called Aplıç Gate ended the 'dead-end' status of the town by enabling the access between north and south.

In 1990, the European University of Lefke was founded and this caused an increase in the population. The university buildings in Lefke, which were built in 2009 and 2015, impacted both the texture and demography of the town.

On January 28, 2014, the traditional town centre of Lefke was declared as an urban protected area (TRNC Official Gazette 2014). The area which is dominated by buildings that have historic, cultural, architectural, and/ or artistic value is classified as a first degree while areas with natural (landscape) and environmental value are identified as second degree protected area (Figure 3) (TRNC Official Gazette 2014). With this decision, the total

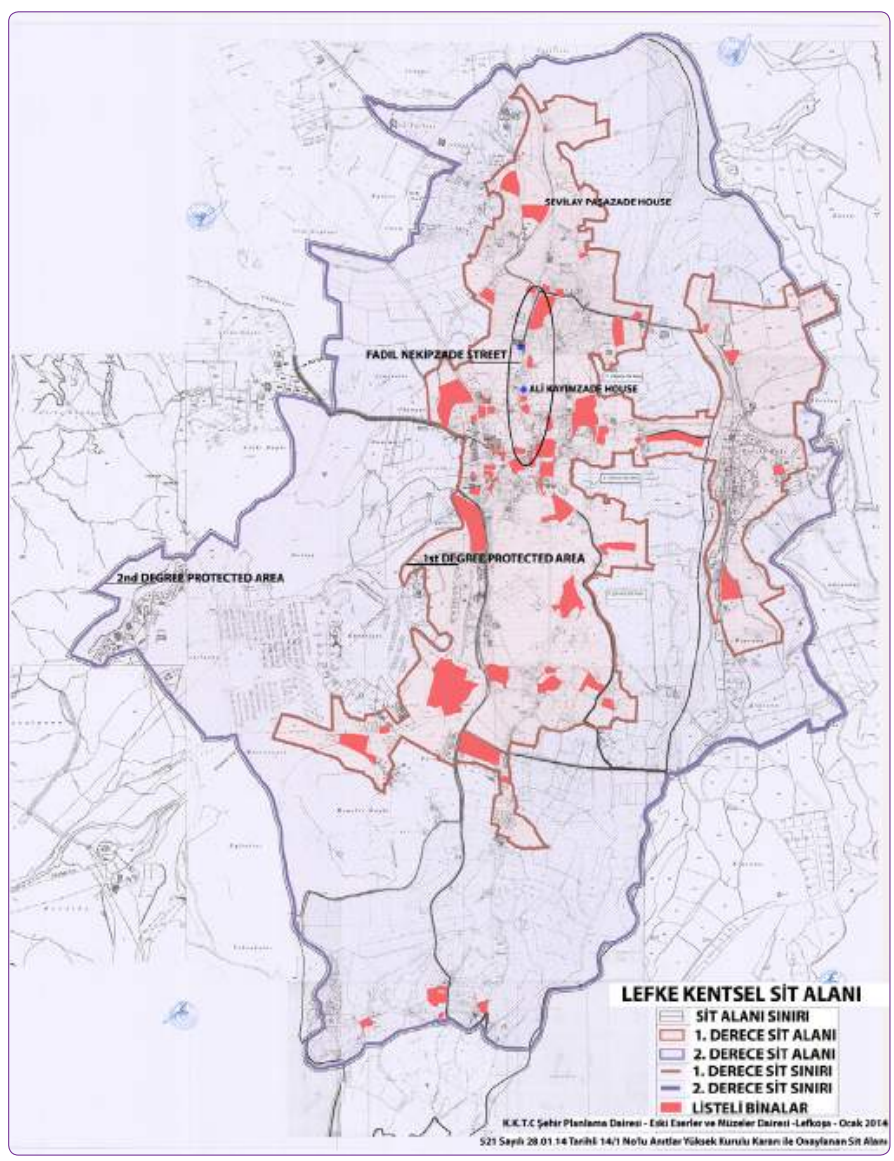

Figure 3. Lefke urban protected area. Source: after TRNC Official Gazette. (2014, February 14), (34), 127, 278-281. number of listed structures which was 41 in 1999 (TRNC Official Gazette 1999) increased to 104. However, because of the lack of supervision, having the supervision only for the projects which apply for approval, the declaration as a protected area has not been sufficient for the conservation of heritage buildings.

On 7 November 2015, as a result of the initiatives of the Municipality of Lefke, the town, together with 13 villages inside the municipal border, became one of the Cittaslow cities. The declaration as a protected area and achievement of gaining the Cittaslow status is important, but an inadequate step in terms of protection and conservation. The absence of a development plan in the region and the late declaration as a protected area resulted in an adverse development, which alters the existing texture and identity. 'Lefke District Development Plan' was finally initiated by the Town Planning Department in 2017 and is still in effect.

\section{Traditional Urban Texture of Lefke}

The traditional urban texture of Lefke is formed by organic narrow streets, cul-de-sacs, houses that define the streets, the water channels running along the streets, and gardens (Figure 4). The single and two-storey masonry mud-brick houses with gable and hipped roofs that

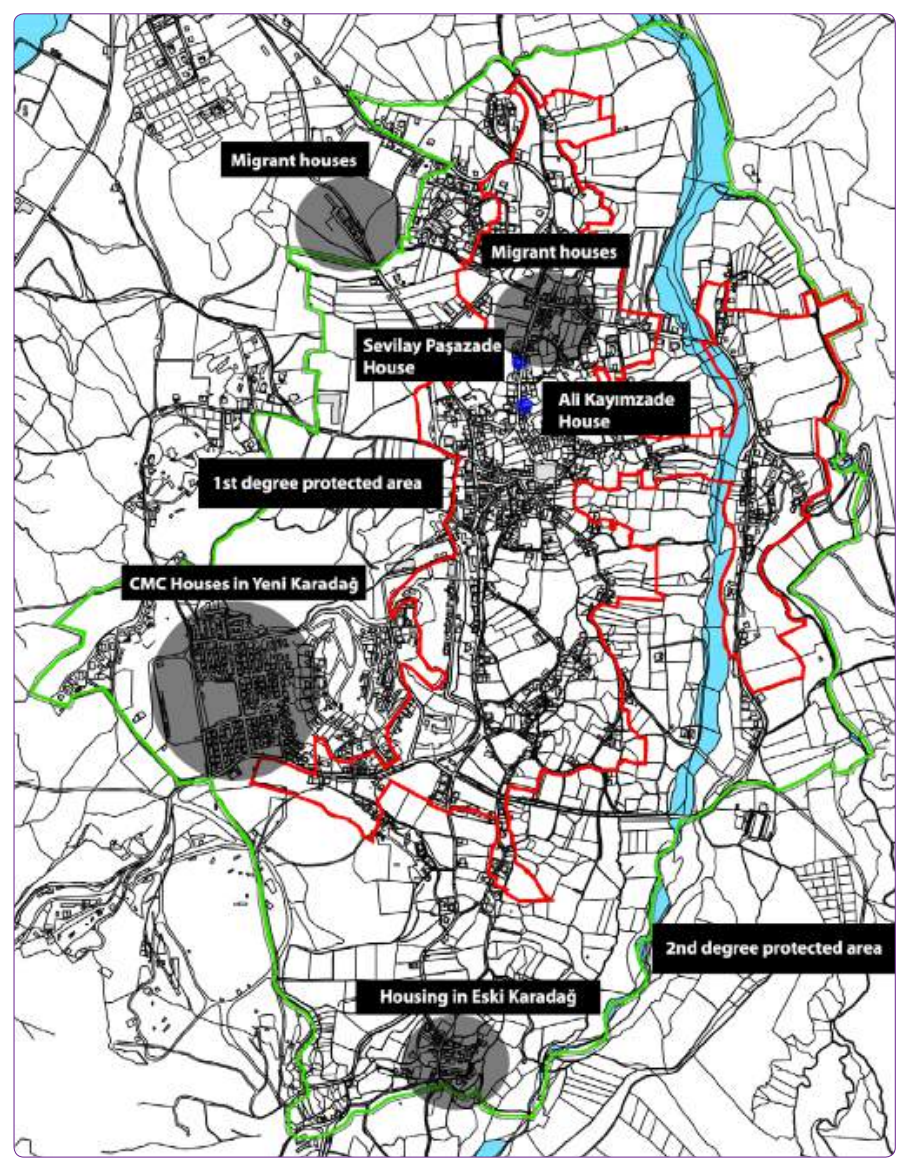

Figure 4. Map of Lefke. Source: Map of Lefke from Municipality of Lefke. 
were built by traditional construction techniques, with courtyards and/or backyards and some with projecting bay are intertwined with the citrus groves.

The urban texture of the town differs in four zones (see Figure 4). The two zones appear as grid organisation. One of them is the CMC houses in Yeni Karadağ (Kırşan, 1998, p.491), which were built by CMC for the administrators, engineers, and workers (Figure 5) and the other is the housing block in Eski Karadağ. The former has the clearest differentiation in comparison to the other three zones. The other two regions are the migrant houses, which were built to accommodate the internally displaced Turkish Cypriots, where the row houses form linear patterns.

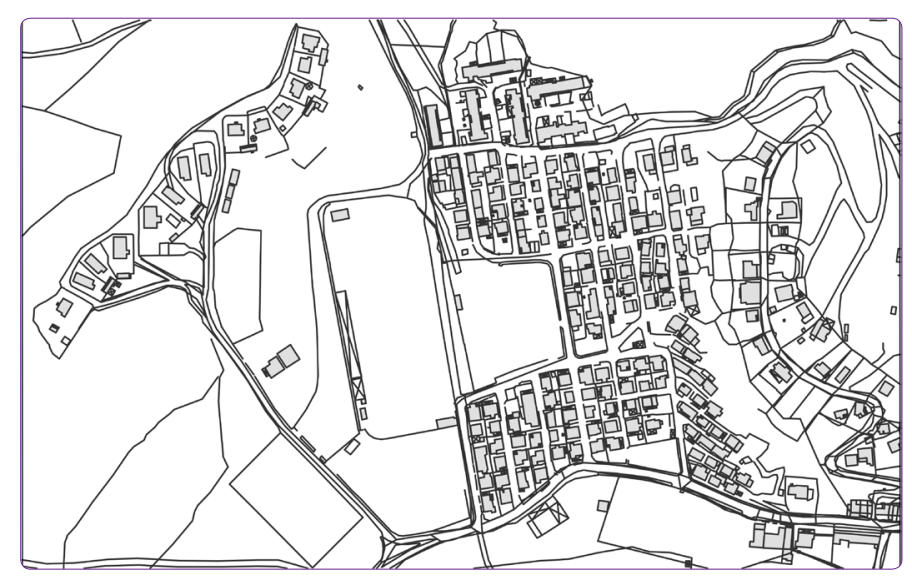

Figure 5. Grid organization of CMC houses in Yeni Karadağ. Source: reproduced from General Surface Map of Cyprus Mines Corporation Mavrovouni Village, 1952, Xero: O.S.A., Drawing Number: A-3111-3, 30.12.1952.
Bandabuliya (covered market), mosques -Orta Camii, Pir Paşa Camii (or Yukarı Camii), Aşağı Camii- tombs, municipality building, British Period Coronation Memorial, public buildings from British Colonial Period built by cut yellow stone; court, post office and district office building and police station, Acendu Church, Acendu Fountain from the Venetian period, historic hotels, commercial buildings like small shops, coffee houses, education buildings, Ottoman and Venetian aqueducts, oil mill, CMC houses and buildings, migrant houses, orange groves, date, and walnut trees are the main elements that have monumental, architectural, socio-cultural values and constitute the traditional urban texture, the cultural mosaic of Lefke together with the traditional houses (Figure 6).

There were four khans (inns) in the traditional town centre. However, none of them have survived. Besides, Pir Paşa Madrasa and the sıbyan (primary) school were the other buildings of the Ottoman period in the town (Bağışkan, 2018, pp.211-218).

The historic town centre of Lefke has an identity that reflects predominantly the architectural character of both Ottoman and British periods. Although Lefke was under Ottoman administration for 307 years and was one of the administrative centres during this period, it has various differentiations from the traditional centres of Ottoman towns in Anatolia. For instance, buildings such as bedesten (covered bazaar), külliye (religious complex), arasta (shops), and aşhane (soup kitchen) are the elements of traditional town centres of Anatolia (Günay, 1999; Bektaş, 2007; Kuban, 2017) and some can be also found in the
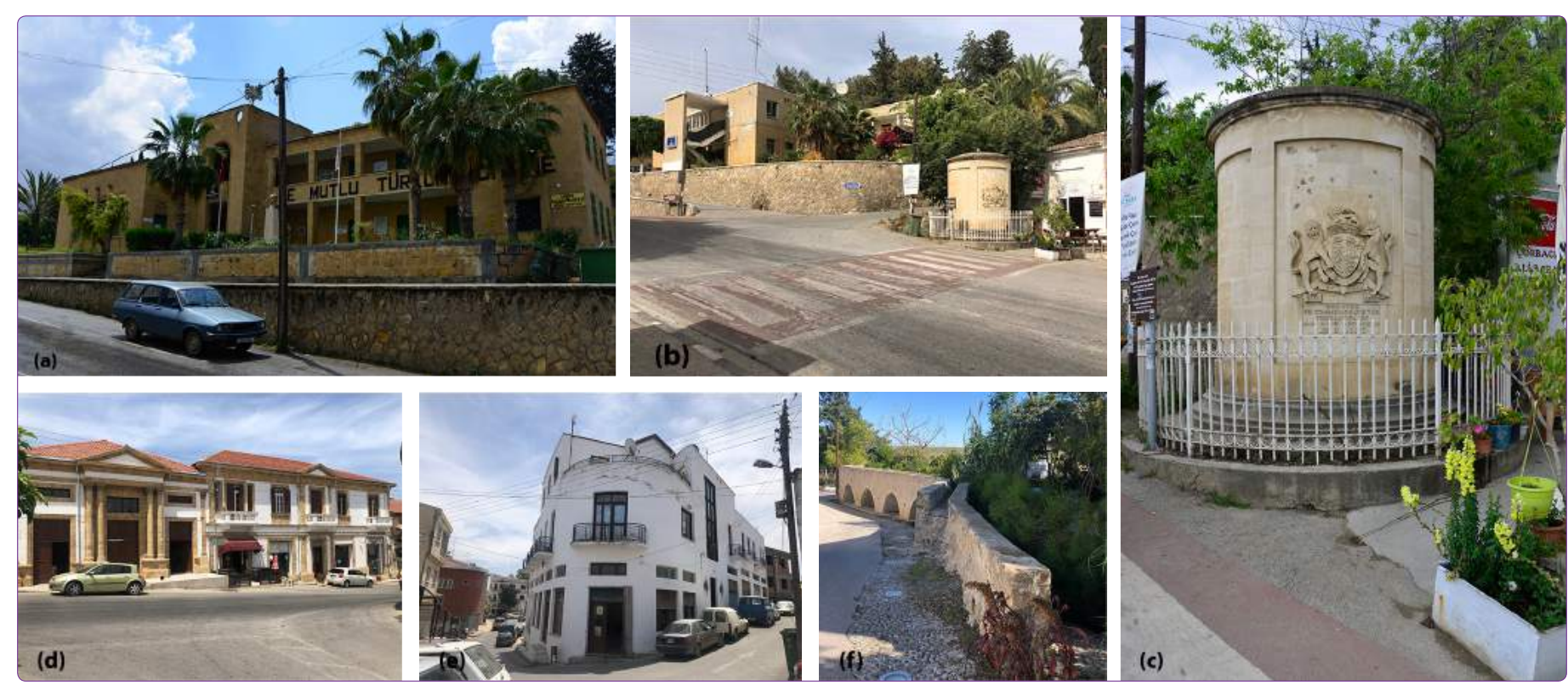

Figure 6. Examples of elements of traditional urban fabric of Lefke. (a) District office, court and post office. (b). Police Station and Coronation Memorial. (c) British Period Coronation Memorial. (d) Vasıf Palace (old hotel). (e) Direk hotel. (f) Aqueducts. Source: Makbule Oktay, March \& April 2019. 

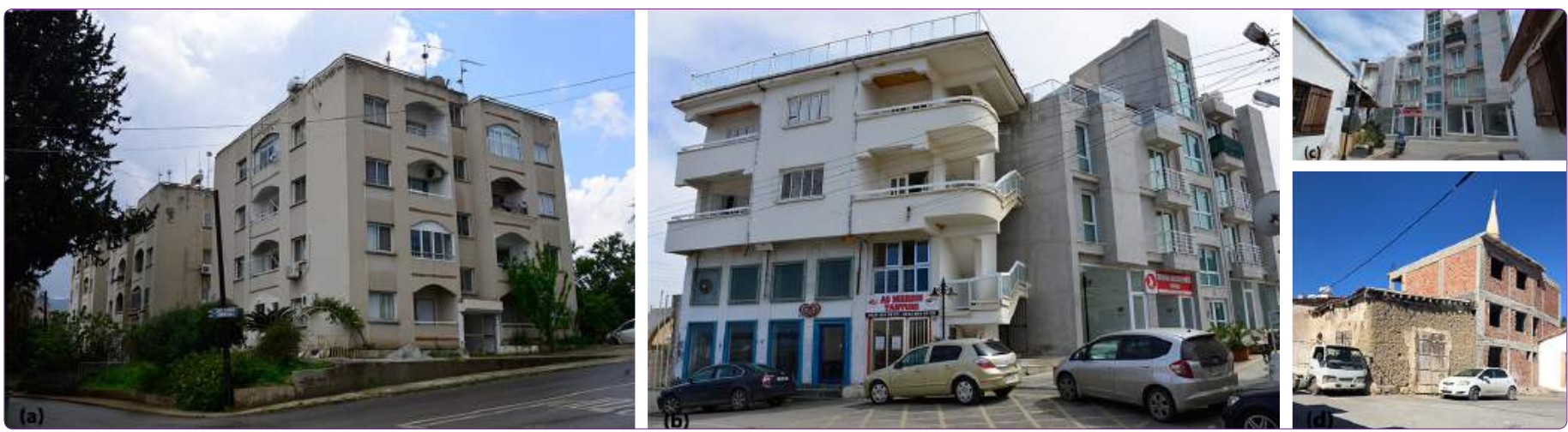

Figure 7. Examples to the buildings which have no relation to the existing texture of traditional pattern of Lefke town centre. (a) Four-storey social housing apartments. (b-d). Multi-story buildings at the town centre. Source: Makbule Oktay, March 2019.

traditional centre of Nicosia, but they do not exist in the traditional town centre of Lefke. This might be related to the size and population of the town.

The buildings which have no relation to the existing texture were injected to the town due to the time elapsed. The four-storey Social Housing Apartments built by the government in 1991, the three or multi-storey buildings built at the heart of the single-storey commercial area stand out as foreign structures that cannot integrate with the traditional texture (Figure 7).

\section{Traditional Houses of Lefke}

In general, traditional houses in Lefke are single or twostorey mud-brick houses with tiled gable or hipped roofs. Some of the two-storey houses have projecting bays, some have exterior sofa/sündürme (hall) as semi-open spaces, some have an interior sofa/sündürme, and some have balconies.

The architectural and urban pattern of Lefke mostly reflects the Ottoman character. However, the multi-cultural environment, climate, and socioeconomic conditions have been effective on the houses, consequently, house formations experienced slight transformations and became a synthesis yet preserved their Ottoman identity (Kırşan, 1998; Oktay, 2000a). Lack of data related to the houses and the settlement fabric before the 19th century preclude academical insight to be had (Kırşan, 1998).

The houses are mainly attached even though there are detached houses. Houses are situated along the street and define the street border. These houses have back gardens and some also have side gardens. Different than the examples of two-storey Ottoman houses with projecting bay, the front garden appears as another element of traditional Lefke houses (Kırşan, 1998; Oktay, 2000a, Oktay, 2000b). Service spaces are situated in the back garden and access to these spaces was from the garden.

House forms adapted according to the topography. Houses that are one-storey on the street side and two- storey on the garden side can be seen in regions where the topography is inclined (Kırşan, 1998, p.500). These types of houses are common in Karşıyaka and Aplıç neighbourhoods.

Some of the houses which were built after 1571 reflect the characteristics of Ottoman Architecture. As it is stated, the 'Turkish House' came to the island after the Ottoman conquest of Cyprus in 1571 and became a typical house of the main towns (Eldem, 1954, p.11). These houses are the symbols of the Ottoman administration on the island.

The sofa and rooms on both sides of the sofa, that can be either close or open to the garden at the back, constitute the main house unit. The sofa is directly accessible from the street and the garden is accessible from the sofa. Access to the upper floor is from the staircase which can be situated either in the sofa or outside. Some of the houses have semi-open spaces - riwaq - on the garden side. (Kırşan, 1998; Oktay \& Tomak, 2019)

Houses that belong to wealthy families are two-storey with projecting bay and situated in big gardens while the houses that belong to modest families are one-storey. There were few wealthy families in Lefke, their houses are similar to each other since they used each other's plan typology as a model and contribute to the spreading of the typology. In the 1930s, 'fake columns' started to appear on the façades indicating that the houses were built by Greek Cypriot builders (Kırşan, 1998, pp.502503). There are also two-storey houses with a balcony on the first floor, above the entrance doors. These houses belong to a period that the projecting bay was replaced by a balcony during the British Period (Pulhan \& Numan, 2005).

Unlike traditional Ottoman houses in Anatolia, the examples of three-storey traditional houses do not exist in Lefke. Therefore, the usage of the ground floor as service floor, middle floor as winter floor and the upper floor as summer floor that can be seen in the Ottoman House examples in Anatolia do not exist in Lefke. Similar to what 
Yükselen (1999) states, it is observed that the ground floors of the houses in Lefke also function as main floors, not as service floors.

Traditional houses in Lefke and Anatolia differ regarding privacy concerns too. In the latter, the ground floors of the houses are either built with solid walls or small openings and are positioned above the eye level so that people who pass through the street cannot see inside (Günay, 1999). Neither of these approaches can be seen in the examples of Lefke. On the contrary, there are openings on ground floors in the same proportion as the openings on the first floor and these openings are not positioned above the eye level. However, other cases also exist where window sizes were enlarged and/or extended to the eye level over time (Yıldız, 1998; Oktay \& Tomak, 2019). Therefore, it can also be argued that the importance given to the privacy may have altered throughout the time.

With these aspects, examples of Ottoman houses in Lefke are similar to the examples in Nicosia. However, twostorey traditional Ottoman Houses with projecting bay in Nicosia and the same type in Lefke slightly differ in few aspects. The traditional houses of Nicosia have defined borders at the back yards while traditional houses in Lefke extend to and connect with the orange groves at the back yards. Besides, some examples of two-storey traditional houses in Nicosia were built on the remains of Lusignan or Venetian buildings (Yıldız, 1998; Pulhan \& Numan, 2006) and constitute hybrid identities. However, as a result of the interviews with the current homeowners who are the descendants and the relatives of the actual homeowners, it is found that all of the two-storey traditional houses with a projecting bay in Lefke were built by their owners from the scratch (Figure 8).

Today, it is seen that some of the traditional houses are still in proper condition, yet some are damaged, some partially damaged and some even demolished. Many reasons might prevent the restoration and conservation of the traditional houses in Lefke and multiple ownership is one of them (Oktay \& Tomak, 2019).

\section{Ali Kayımzade House}

Ali Kayımzade House in Fadıl Nekipzade Street is located inside the 1st degree protected area. The house was built in 1940 and was listed in 1999. It was recently renovated and there is no structural damage on the building (Figure 9). This house is not in constant use. It is used only on a certain day of the week and sometimes at the weekends.
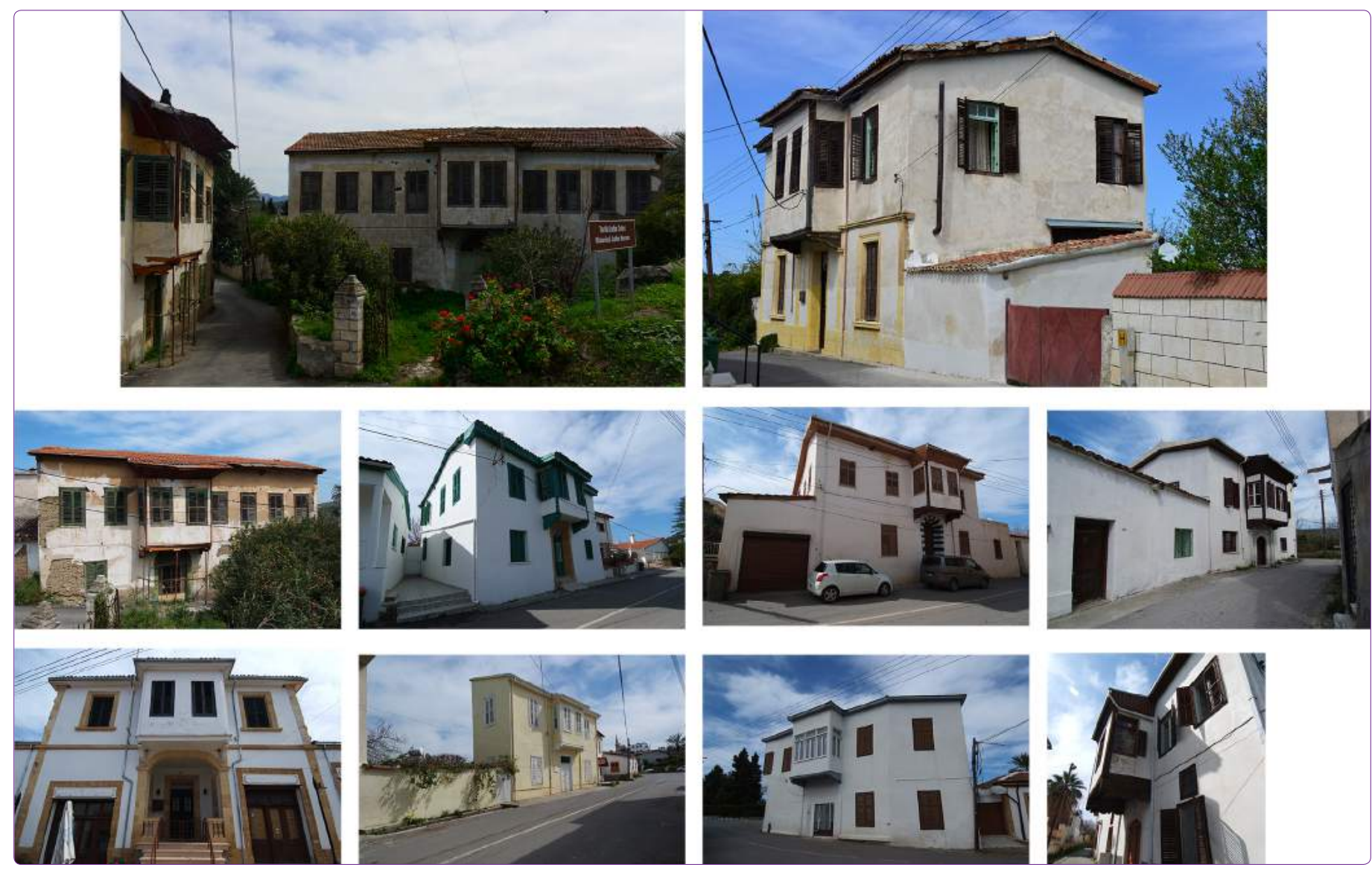

Figure 8. Two-storey traditional Ottoman houses with projecting bay in Lefke. Source: Makbule Oktay, March \& April 2019. 


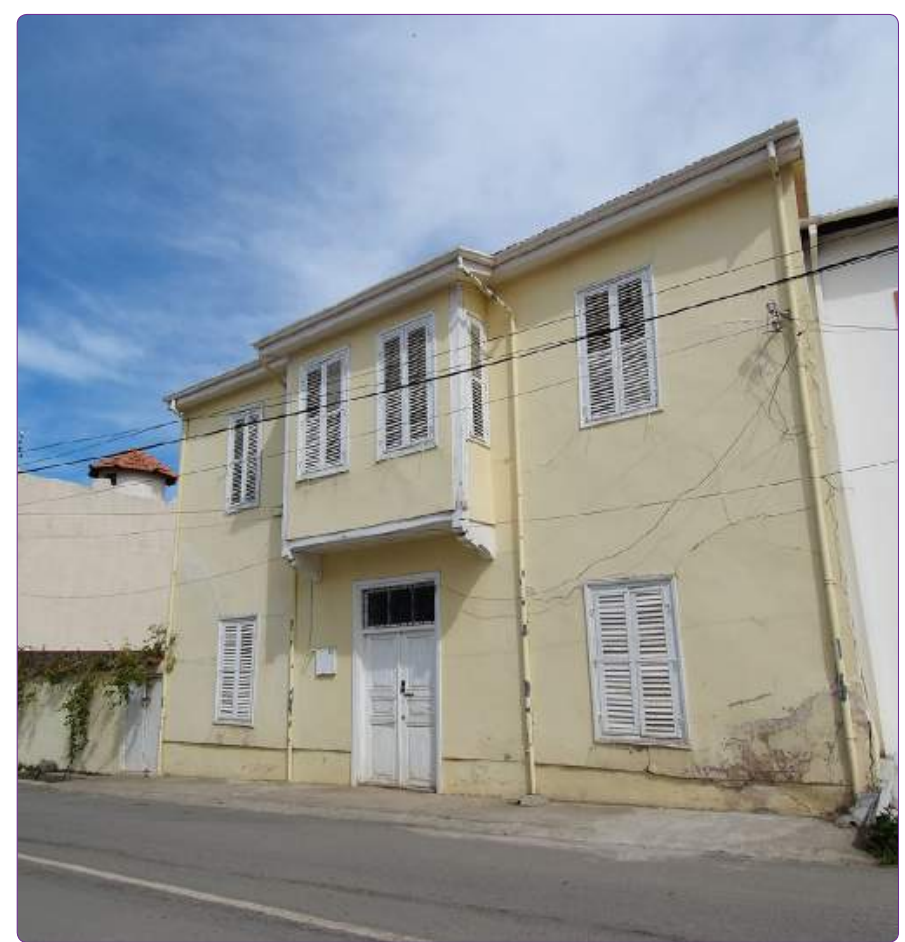

Figure 9. Ali Kayımzade house. Source: Makbule Oktay, March \& April 2019.

\section{Building Plot - Building Relationship}

The house is positioned parallel to the street and defines the street. It is located at the corner of the plot and the garden covers the side and back. The house is attached to

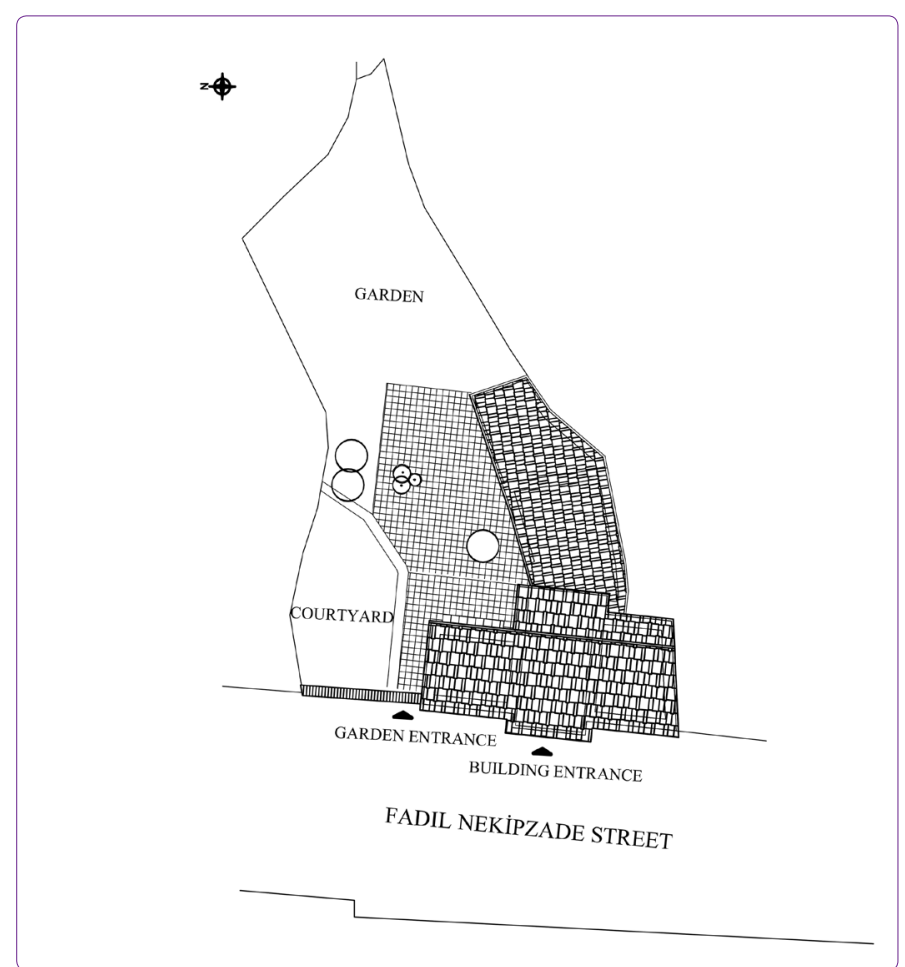

Figure 10. Building plot - building relationship, site plan. Source: Makbule Oktay, December 2018. another two-storey house on the south façade while the north façade is facing the side garden (Figure 10). There are two entrances to the house from the street. The first entrance is directly from the street to the ground floor sofa and the second entrance is from the side to the garden. Compared to the main entrance door, the garden door is lower, narrower, and simpler.

\section{Plan Typology and Spatial Use}

The house is an example of a two-storey inner sofa type which is one of the four main types that Eldem (1954) has identified (Figure 11). On the ground floor, there is one room on both sides of the sofa - or as locally called 'sündürme'. In this type of houses, sofa on the ground floor acts as a functional transition area that prepares people from public space to enter into the private territory. A U-type wooden staircase located in the sofa leads up to the upper floor sofa. Access to the courtyard is from the room on the north of the sofa. Previously, all the rooms on the ground floor were used as living spaces. Formerly, the sofa was used as a sitting and transition space, room on the north of the sofa was used as a daily sitting room and a room on the south of the sofa was used as a guest sitting room. Currently, while the two rooms still function in the same way, the room on the south of the sofa serves as storage (Figure 12).

The kitchen, the bathroom, and the toilet were the auxiliary rooms - service spaces - made of adobe and were attached to the main building. These spaces were only accessible from the garden. With the changes made, direct passage to the kitchen from the sofa was provided. The adobe bathroom and toilet were demolished and replaced by a toilet and bathroom, and direct access was provided from the kitchen.

On the first floor, there is a sofa and two rooms. During the childhood of the homeowner, the room in the north was the master bedroom, the room in the south was a children's bedroom and the sofa was used as a sitting area and transition space. However, as the number of children increased, the sofa was then used as a bedroom. Now, it is again used as a sofa (Figure 13).

Unlike traditional houses in Anatolia, the rooms in this house do not include areas like 'seki alt' (shoe cupboard) and elements like 'yüklük'(wardrobe). Besides, 'ocak' (fireplace) which is a common element of rooms in the traditional houses in Anatolia is only seen in the kitchen of this house. According to Kuş̧̧u and Kuşçu (1996), the absence of this type of spaces was the impact of Westernisation on a traditional Turkish house in the nineteenth century. Similarly, Yıldız (1998) claims that the traditional Ottoman houses in Cyprus started to transform in the $18^{\text {th }}$ century. 


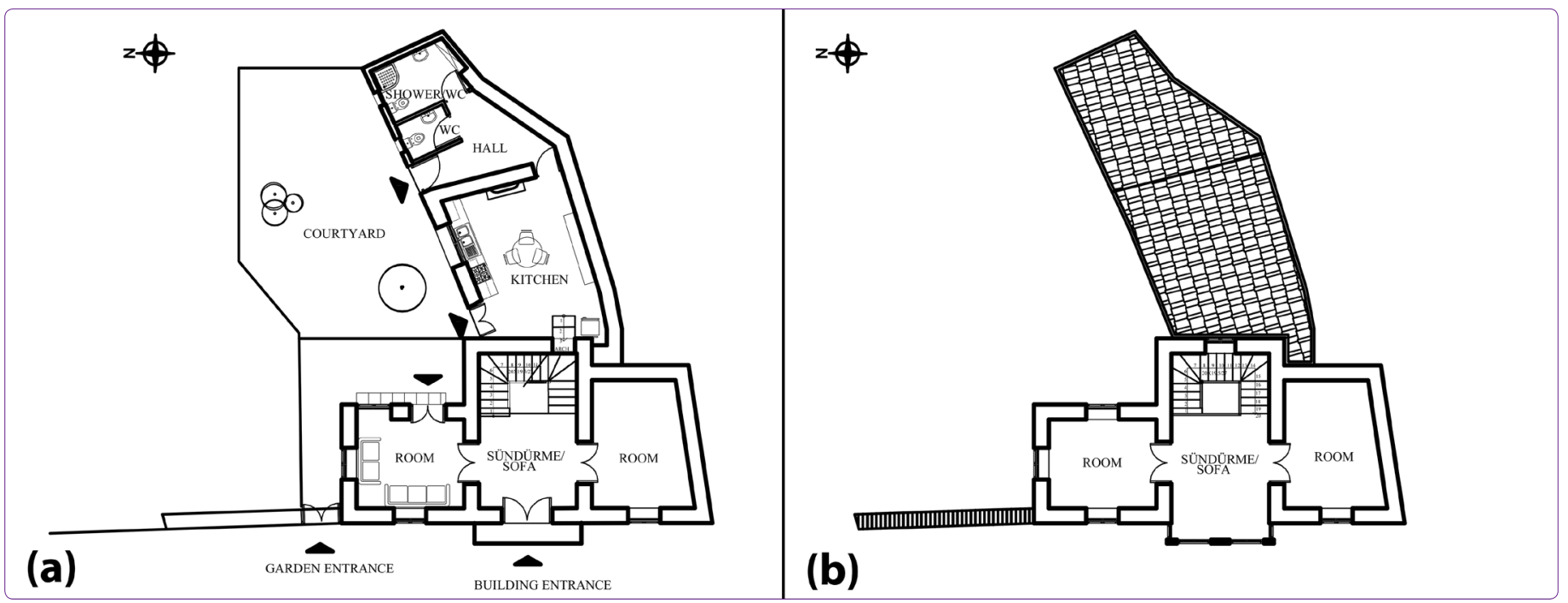

Figure 11. (a) Ground floor plan. (b) First floor plan. Source: Makbule Oktay, December 2018.
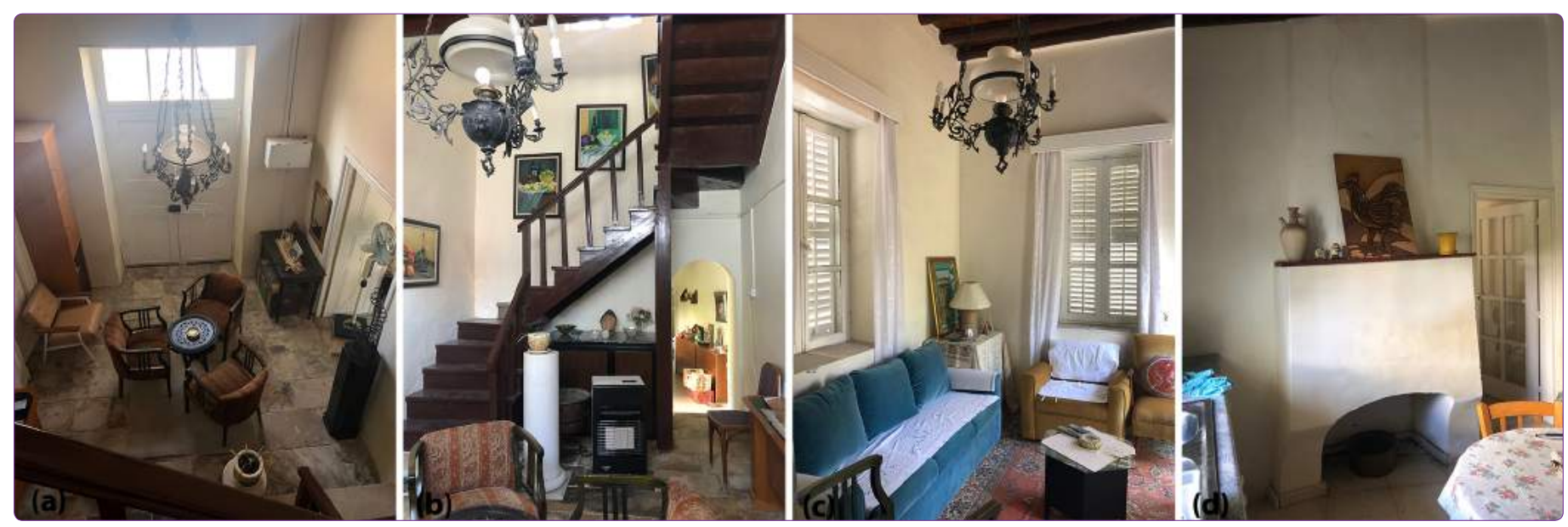

Figure 12. (a, b) Ground floor sofa views. (c) Ground floor room view. (d) Kitchen view. Source: Makbule Oktay, November 2018.
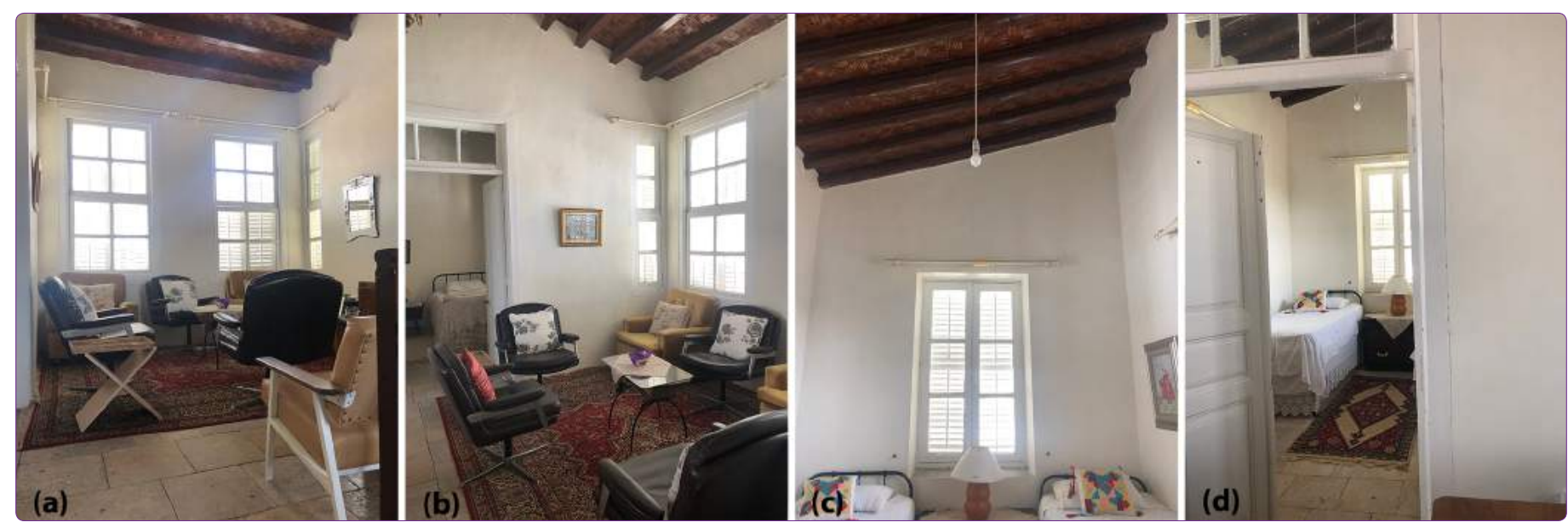

Figure 13. (a, b) First floor sofa views. (c, d) First floor room views. Source: Makbule Oktay, November 2018.

\section{Façade Features}

The most prominent façade feature in this house is the projecting bay (Figure 14). Projecting bay has narrow and long windows with wooden shutters. It is the extension of the upper sofa to the street. This extension functions both socially and climatically. On the front façades facing 

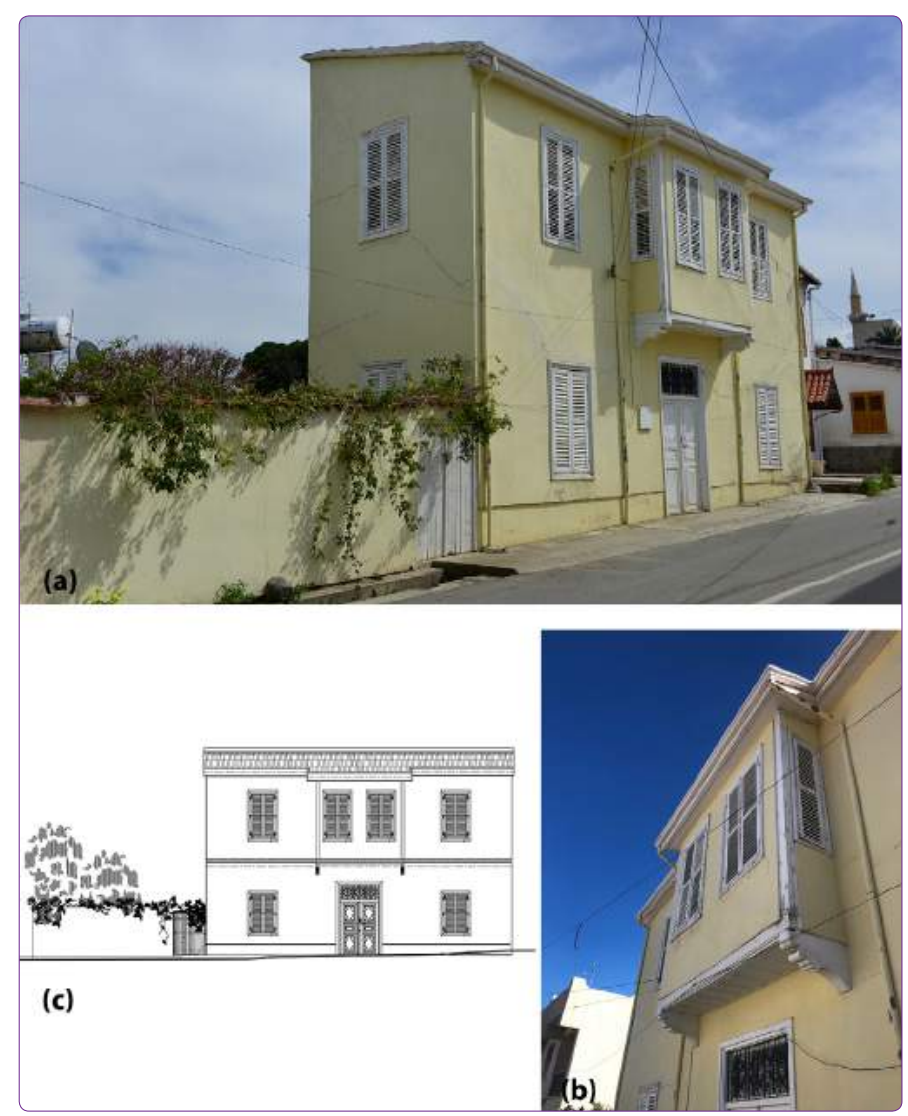

Figure 14. (a) North façade and west - entrance façade of the house. (b) Projecting bay. (c) West - entrance façade of the house. Source: Makbule Oktay, December 2018 \& March 2019.

the narrow streets, this mass overlooks the street, enables exterior air to circulate inside the house through the openings on two opposite surfaces and on the front surface. Besides, these openings allow homeowners to watch the life on the street. This structure extends $70 \mathrm{~cm}$ to the street and is supported by wooden buttresses.

The front façade organisation of the house is symmetric. The entrance door of the house is situated in the middle of the façade and the projecting bay is above the entrance door. On the right and left side of both the entrance door and the projecting bay, there are four rectangular windows. Ground floor and upper floor window sizes are $108 \mathrm{~cm}$ $\times 169 \mathrm{~cm}$, and $108 \mathrm{~cm} \times 192 \mathrm{~cm}$, respectively. Window systems are casement and vertical slider - guillotine. All windows have wooden shutters.

The size of the main entrance door is $171 \mathrm{~cm} \times 290 \mathrm{~cm}$. There is a glass section on top of the wooden door to enable the daylight to reach the sofa. A decorative iron insert is positioned in front of the glass section. The dimension of the garden door is $125 \mathrm{~cm} \times 171 \mathrm{~cm}$. The room doors are wooden doors with double wings. There are fixed glass top sections on the upper part of the doors. The door handles of the rooms are made of wood while the entrance and garden door knockers are made of iron (Figure 15).
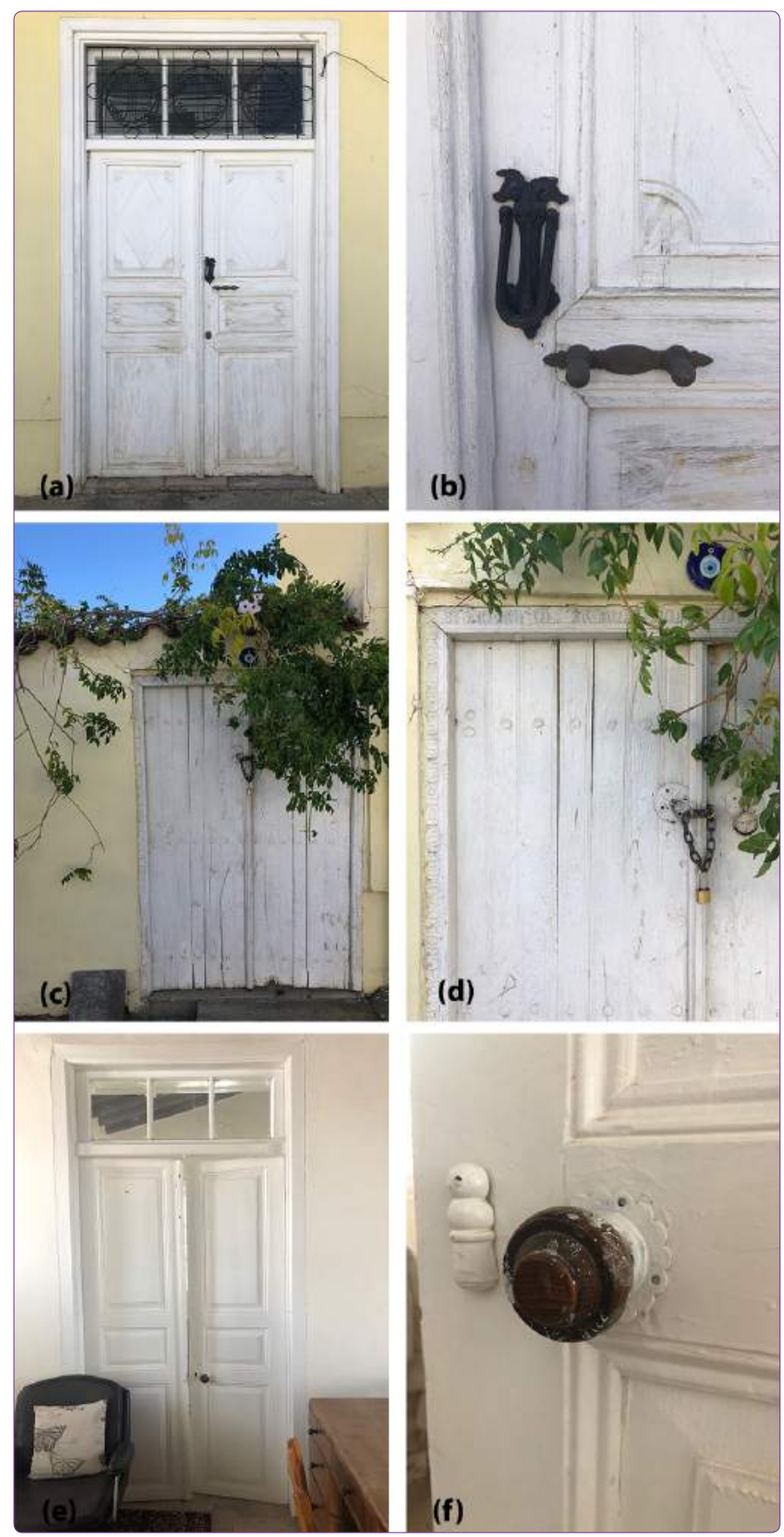

Figure 15. (a) Main entrance door. (b) Main entrance door detail. (c) Garden entrance door. (d) Garden entrance door detail. (e) Example of interior door. (f) Example of interior door detail. Source: Makbule Oktay, November 2018.

There is a $210 \mathrm{~cm}$ high wall that runs parallel to the street and separates the courtyard from the street. The high garden wall, which is related to street-courtyard division and associated with privacy, is similar to the examples in Anatolia. While the space behind the wall is hidden and cannot be seen while passing by, the trees and flowers that rise above the wall and overflow to the street give clues about the life inside. 


\section{Building Materials and Construction Technique}

Mud-brick, timber, bamboo mat, and local marble are the main building materials of the Ali Kayımzade house. The house is a masonry structure made of mud-brick. The thickness of the adobe walls is $50 \mathrm{~cm}$. Walls are originally plastered by gypsum but now are painted white. The floors of the house are covered with marble. The ceiling of some rooms consists of rounded, some rooms of rectangular wooden rafters. Rafters are situated on load-bearing masonry walls with approximately $25-35 \mathrm{~cm}$ intervals. In general, the dimension of the rooms has been determined by the dimension of the rafters. The upper floor ceiling has a bamboo mat on wooden rafters and marble on the bamboo mat. The roof is a gable roof cladded with Marseille tiles (Figure 16).

\section{Sevilay Paşazade House}

Sevilay Paşazade house is located on the Fadıl Nekipzade Street and is located inside the 1st degree protected area. The house was built in 1927 and was listed in 1999. It is in continuous use and no structural damage is observed (Figure 17).

\section{Building Plot - Building Relationship}

Like the aforementioned Ali Kayımzade house, this house is located parallel to the street and defines the street. On the backside of the house, there is a twoacre citrus garden. The house is located at the corner of the plot, attached to a neighbouring house in the north direction and detached from the south direction where there is a passage to the backyard (Figure 18).

\section{Plan Typology and Spatial Use}

The house, which was built as a two-storey house was then divided into two houses, as lower and upper houses. The lower floor is rented usually to students while the upper floor is inhabited by the homeowners. There are two separate entrances to the house. The first entrance is directly from the street to the ground floor sofa. This entrance acts as the entrance of the lower house. The second entrance is from the garden door at the side of the house. From this door, there is access to the staircase which has been built at the time when the house is divided into two individual houses. The staircase leads to the upper floor entrance door.

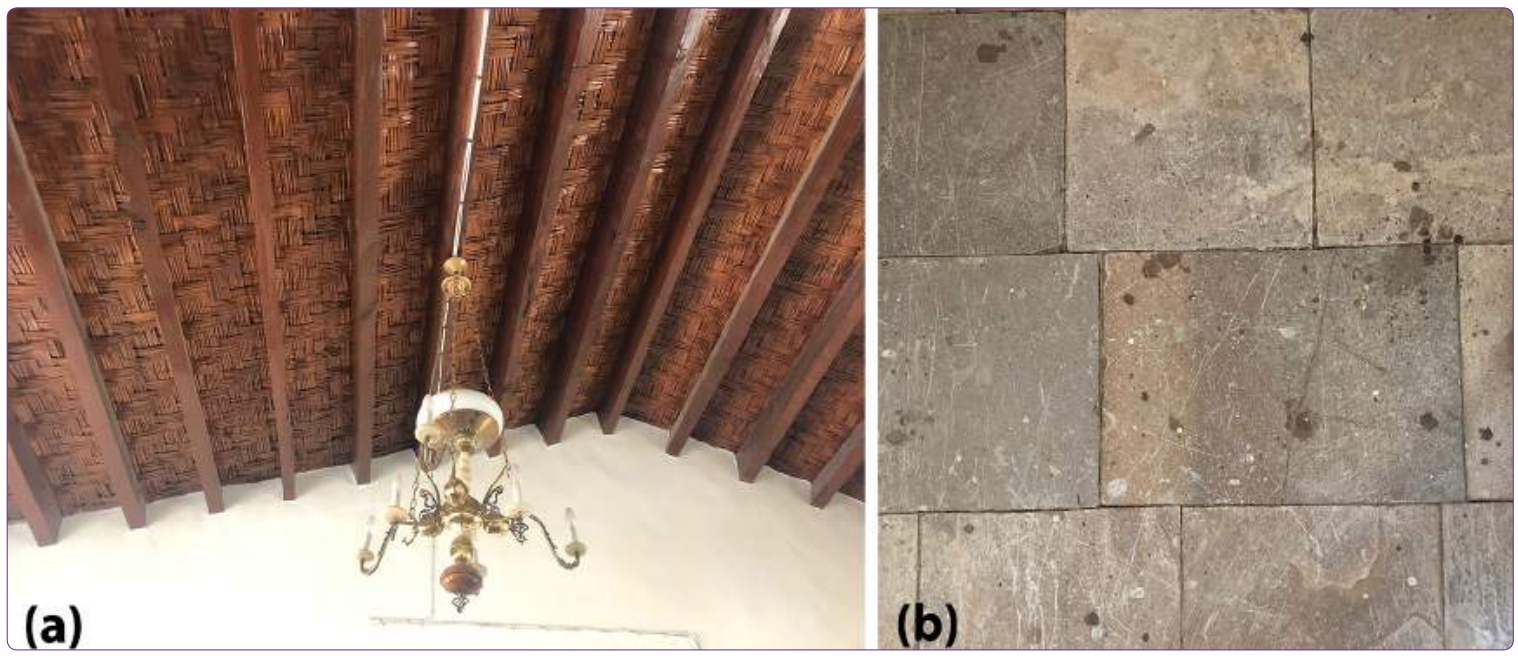

Figure 16. Building materials. (a) Ceiling materials. (b) Floor material. Source: Makbule Oktay, November 2018.

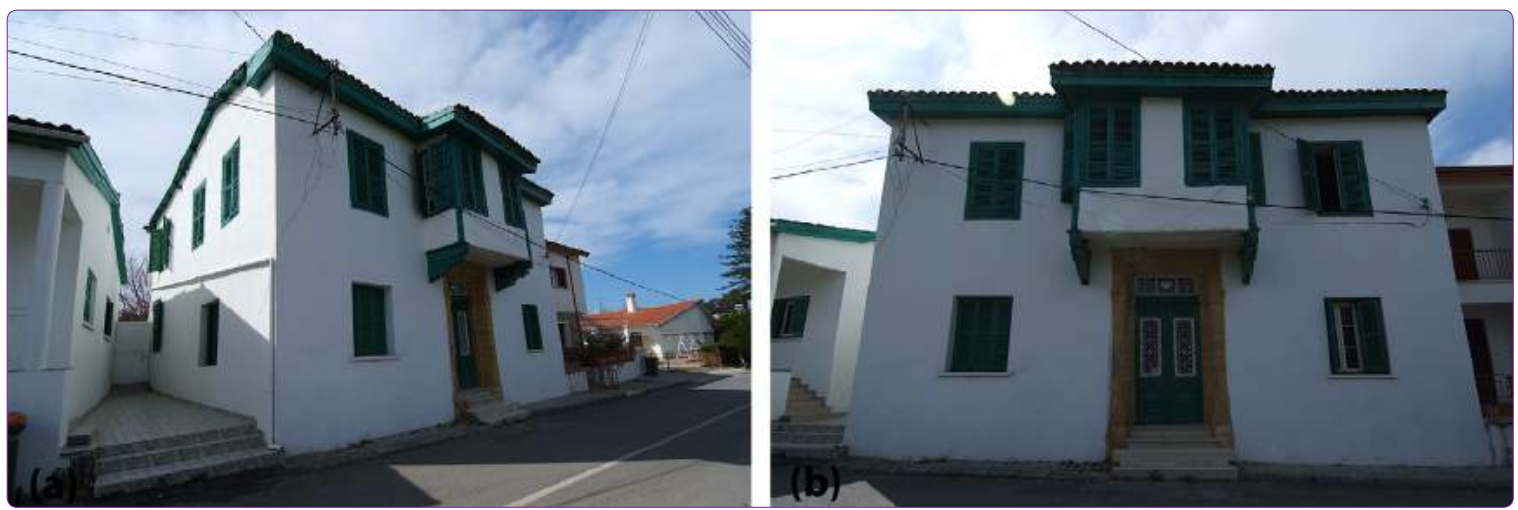

Figure 17. Sevilay Paşazade house. (a) South and east façades. (b) East façade. Source: Makbule Oktay, March 2019. 


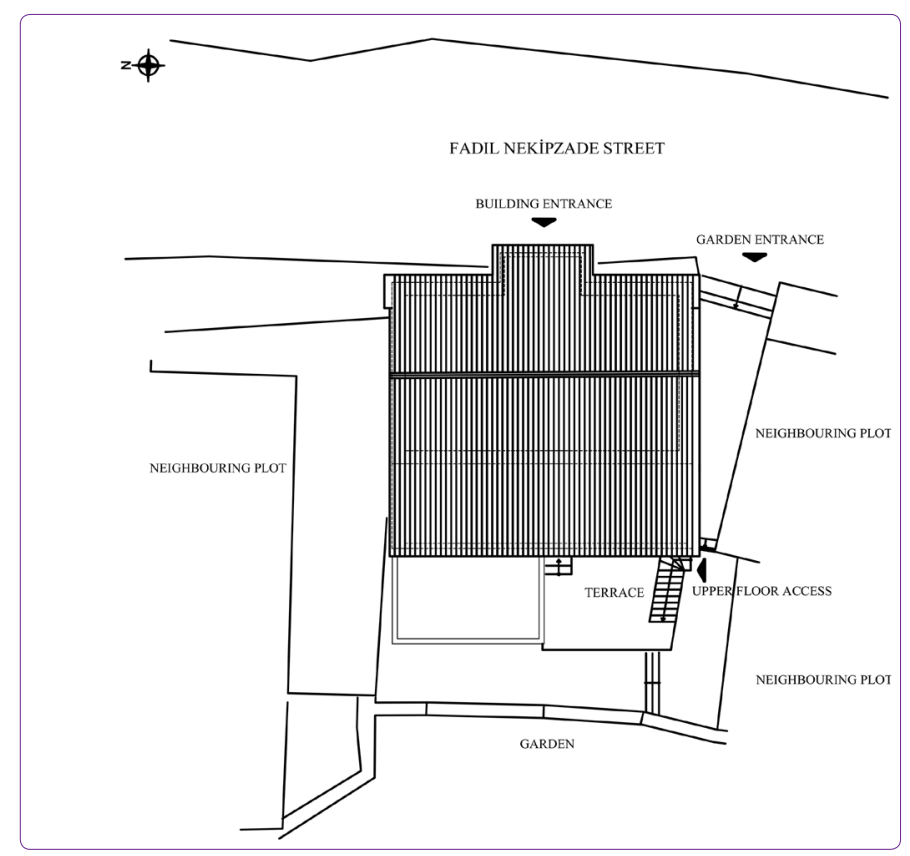

Figure 18. Building plot - building relationship, site plan. Source: Makbule Oktay, March 2019.

The house is a traditional two-storey inner sofa type with a projecting bay (Figure 19). On the ground floor, there is a sofa in the middle, two rooms on the south of the sofa, one room on the north and a spiral staircase which leads to the upper floor. Before the changes, there was access to the back garden from the sofa. When the building was divided, a kitchen, a bathroom, and a toilet were added to the ground floor, which are accessible from the sofa. There were five single-storey service spaces made of adobe located in the garden. These were 'alttan yanma hamam' bath with floor heating, 'soğukluk'- cooling room, kitchen with an oven in it, storage and laundry. Four of these rooms were demolished by the homeowners while one of them is still used as a storage.

In the former use of the house, on the ground floor, the room on the north of the sofa was used as a guest sitting room and the room on the south was functioning as a daily sitting room. The daily sitting room was projected about two metres to enable the construction of a hearth. Then, when the house in the neighbouring plot was about to be built, the size of the room was reduced and the room became aligned with the upper floor. In the following years, the guest sitting room and daily sitting room were converted into bedrooms.

Before the changes, there were a sofa and three rooms on the upper floor. During the childhood of the homeowner, the room on the north was a guest bedroom, the room facing the garden was a children's bedroom, the large room facing the street was the master bedroom and the sofa was a sitting area. When the building was converted into two different houses, an outer staircase to provide access to the upper floor, a terrace, a kitchen, a bathroom, and a toilet were added. The entrance of the upper floor is provided by converting the existing window of the sofa into a door. The sofa sustained its function. The first room on the south of the sofa is the living room, the second room is the bedroom, and the room on the north of the sofa is a bedroom (Figure 20). The space configurations and interviews with the homeowners and locals and existing literature (Kırşan, 1998; Yükselen, 1999;

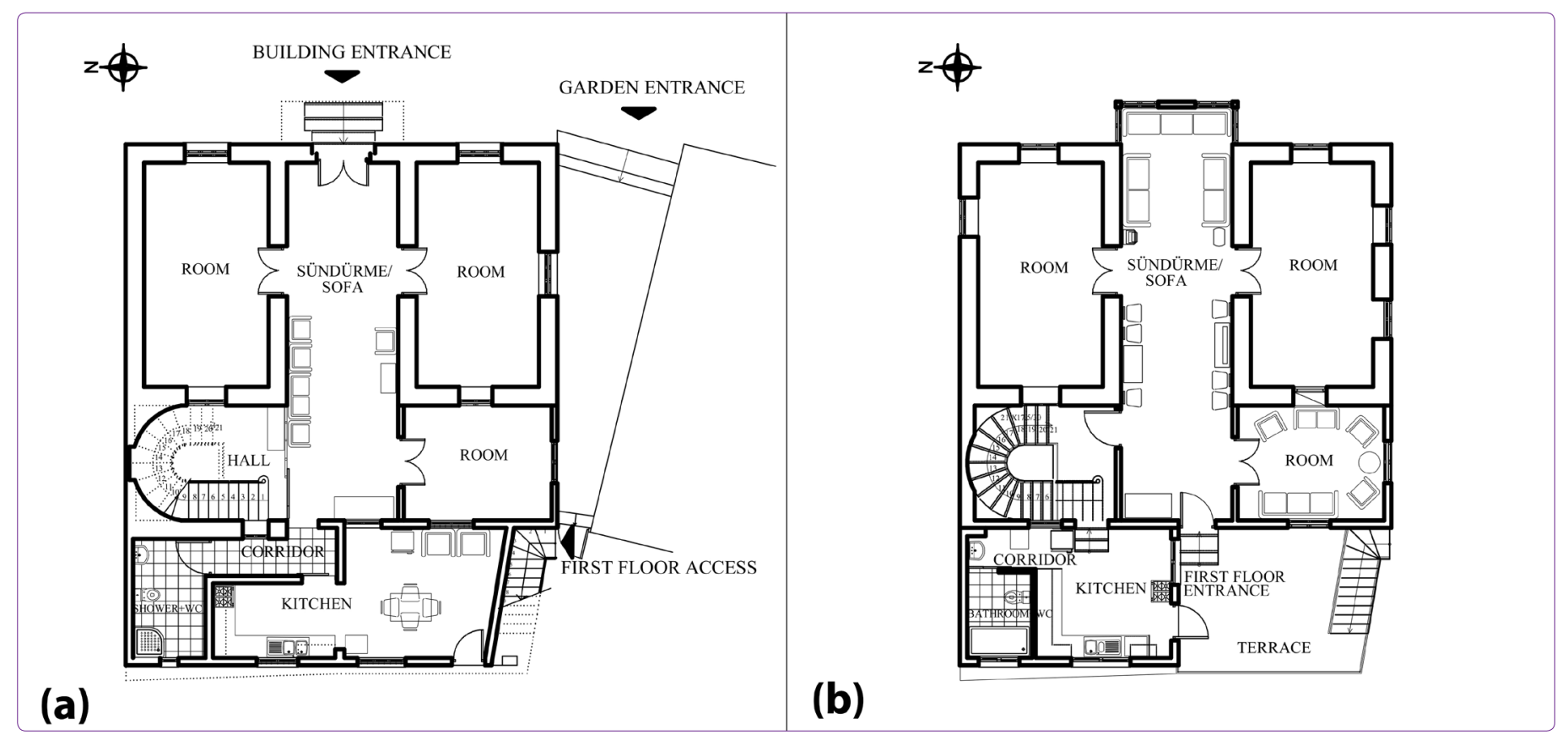

Figure 19. (a) Ground floor plan. (b) First floor plan. Source: Makbule Oktay, March 2019. 

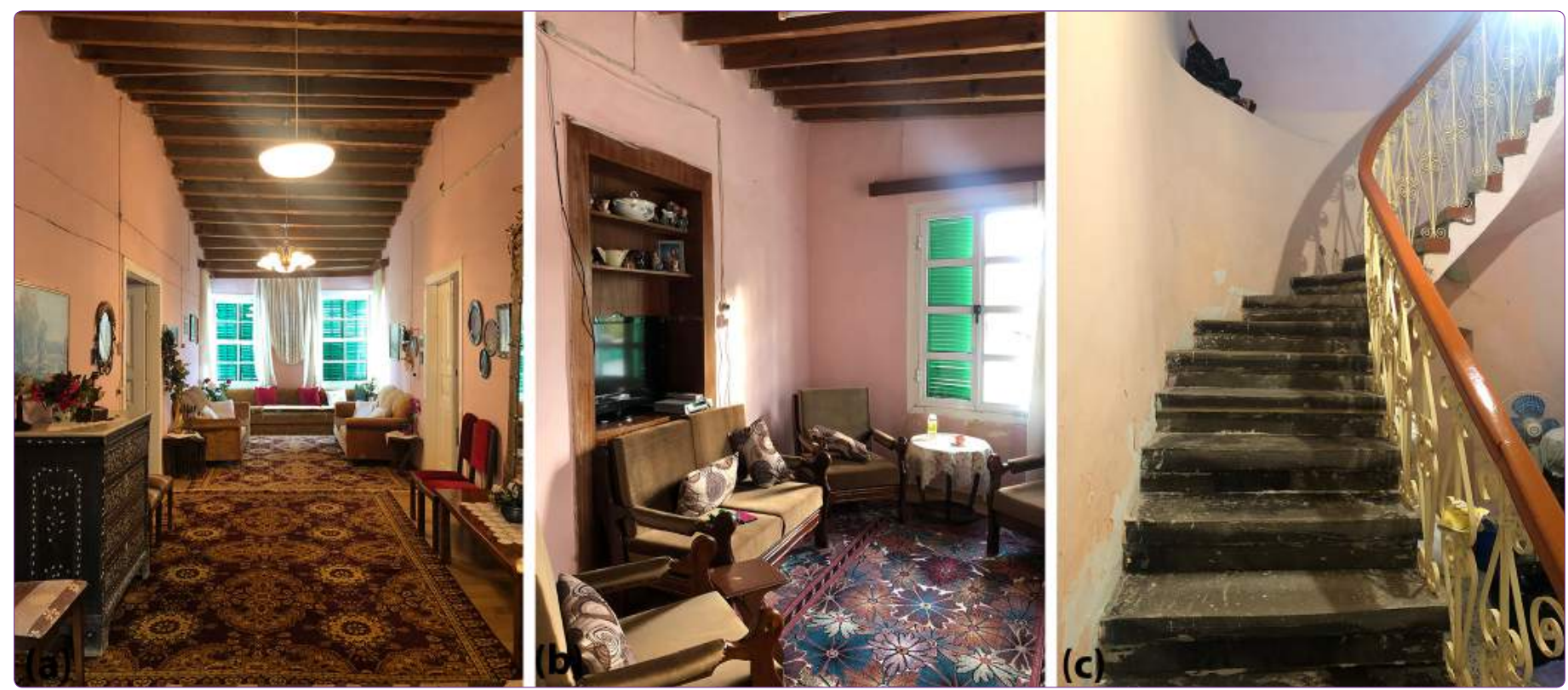

Figure 20. (a) First floor sofa view. (b) First floor room view. (c) Staircase. Source: Makbule Oktay, November 2018.

Oktay, 2000a; Oktay, 2000b; Oktay and Tomak, 2019) revealed that the rooms in the traditional Lefke houses were not multifunctional.

In contrast to the examples in Anatolia, similar to the Ali Kayımzade house, there is no 'seki alt'. There was a narrow closet between the master bedroom and the children's bedroom which could have been a small 'yüklük'. However, it was transformed into a door by the current users. Now it is a shelf on the bedroom side and a television unit by the living room side.

\section{Façade Features}

The most noticeable façade feature of this house is the projecting bay as well (Figure 21). It is projected about 115 $\mathrm{cm}$ and is supported by wooden buttresses. The symmetry is dominant on the front façade. The entrance door is in

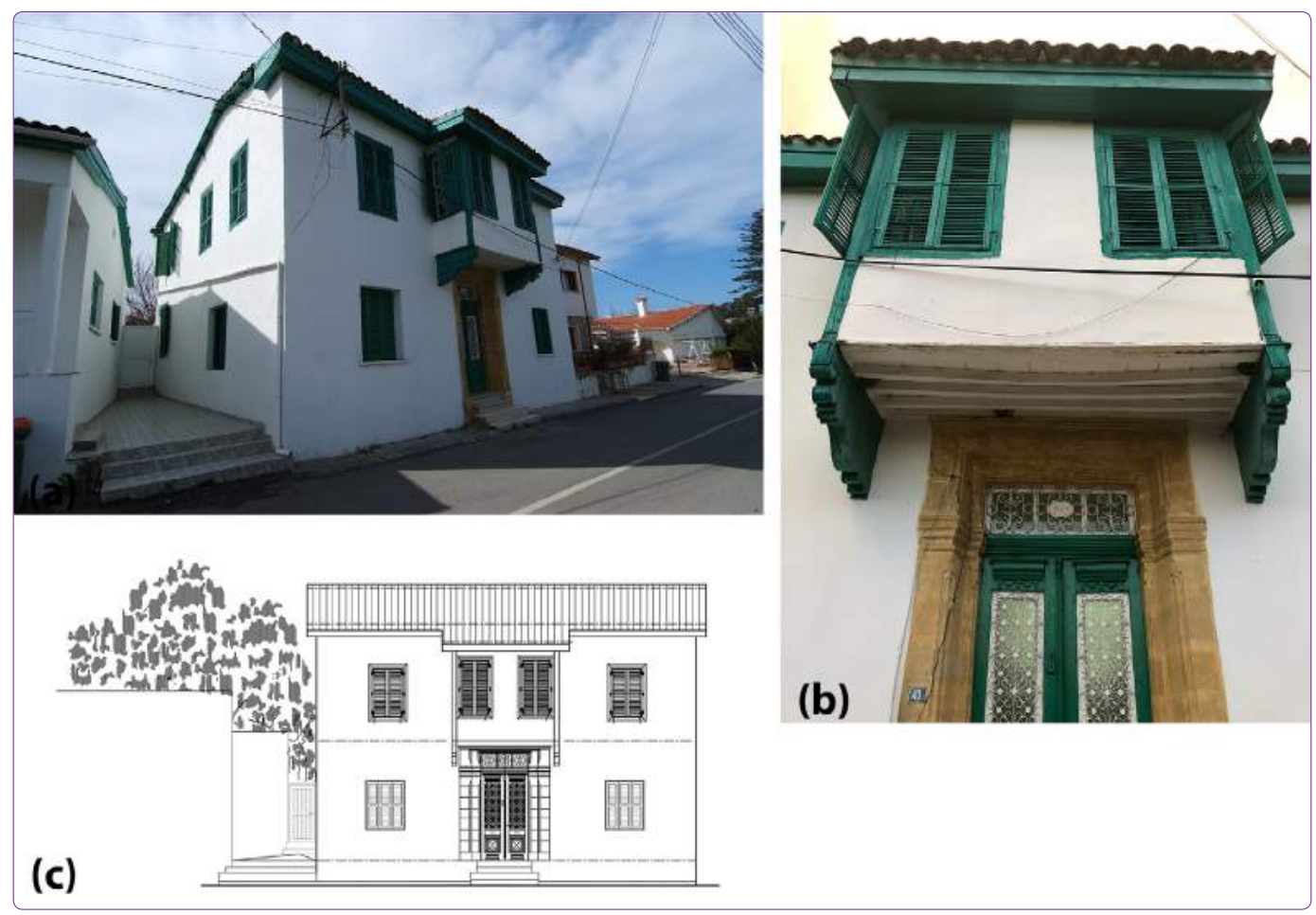

Figure 21. (a) South façade and east - entrance façade of the house. (b) Projecting bay. (c) East - entrance façade of the house. Source: Makbule Oktay, March 2019. 


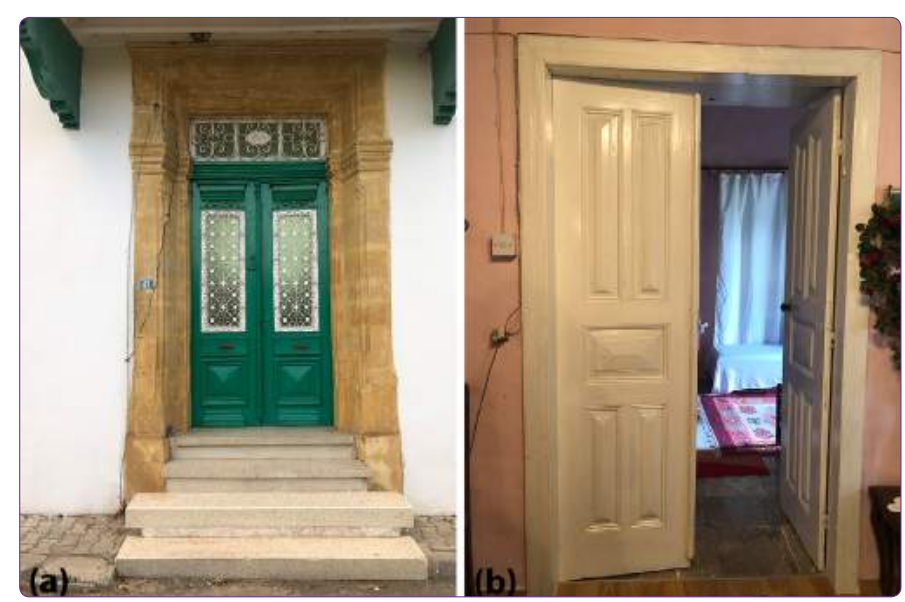

Figure 22. (a) Main entrance door. (b) Example of interior door. Source: Makbule Oktay, November 2018.

the middle of the ground floor. A projecting bay is located above the entrance door. There are four windows on the projecting bay, two of which were on the front façade and one on each side façades. There are four windows on the front façade; on each side of the entrance door on the ground floor and two on each side of the projecting bay on the upper floor. The windows are rectangular. The size of the front windows of the projecting bay are $100 \mathrm{~cm}$ $\times 82 \mathrm{~cm}$. The upper floor and the ground floor window dimensions are $106 \mathrm{~cm} \times 166 \mathrm{~cm}$ and $114 \mathrm{~cm} \times 145 \mathrm{~cm}$, respectively. Window systems are casement and vertical slider - guillotine. All windows in all façades have wooden shutters except for the additional spaces.

The entrance door is $145 \mathrm{~cm} \times 332 \mathrm{~cm}$. There is a glass section on top of the door. A date is written on a decorative iron window insert which is positioned in front of the glass section. The door is a combination of glass and wood. There is a yellow cut-stone frame, resembling columns 'fake columns', around the entrance door. The room doors are double-wing wooden doors. There are fixed glass parts on the upper part of the doors. The door handles are made of wood while the entrance door knock is made of iron (Figure 22).

\section{Building Materials and Construction Technique}

Sevilay Paşazade house is a masonry mud-brick structure. Mud-brick, timber, bamboo mat, and local marble are the main building materials. As explained by the homeowner, the earth where the house is situated now is used to produce an adobe for the construction of the house. The thickness of the adobe walls is $50 \mathrm{~cm}$. The walls used to be plastered with gypsum are now painted white. The upper floor of the main building is covered with traditional marble and the lower floor is covered with marble. The floor of the sofa on the first floor was replaced with wooden parquet. The building material of the service spaces and additions are brick and floors are tiled.

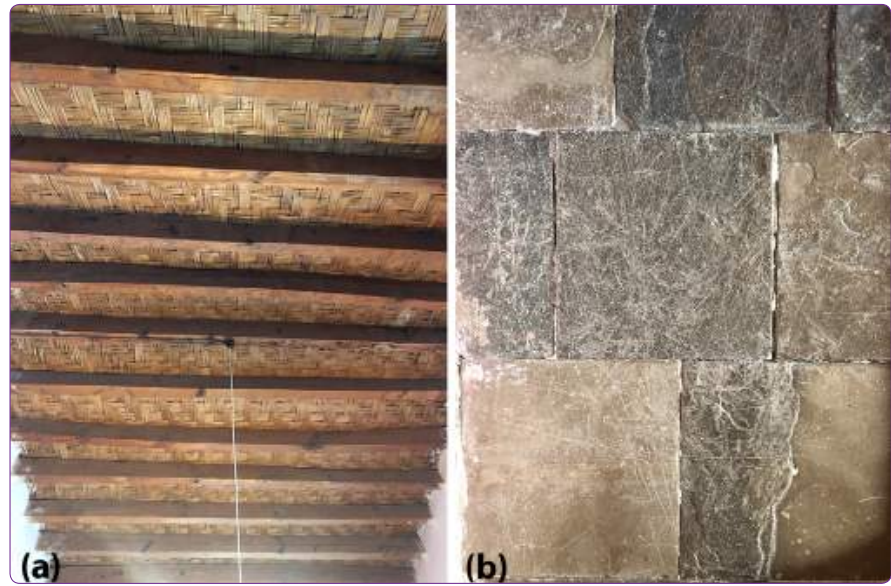

Figure 23. Building materials. (a) Ceiling materials. (b) Floor material. Source: Makbule Oktay, November 2018.

The ceiling on the first floor consists of a bamboo mat laid on rectangular wooden rafters (Figure 23). Rafters are situated on load-bearing masonry walls. Rafters are located on two different directions on the upper floor sofa. Mainly they are situated on the masonry walls while some of them placed on a wooden beam. The intervals between rafters are roughly $25-35 \mathrm{~cm}$. The ground floor ceiling was changed to fibreboard. The roof is a gable roof and covered with traditional terracotta tiles.

To sum up, Ali Kayımzade house and Sevilay Paşazade house are two examples of traditional Ottoman houses that were built in the British Period. Although plan typologies of the two houses are similar, they differentiate by changes in plan organisations and spatial usage. In the former, which is in use at certain times, the change is less compared to the second house which is in constant use. By considering these two examples, it can be argued that continuous use might necessitate more change. Also, the reason for the change can be related to the decrease in the number of users, as well as for economic reasons. Thus, these cannot be generalized unless more examples are investigated.

By considering these two examples and the ones that have been covered in previous studies (Kırşan, 1998; Yükselen, 1999; Oktay, 2000a; Oktay, 2000b; Oktay and Tomak, 2019), spatial organisations and former functions of the spaces suggest that the rooms in the traditional Lefke houses which were built in the British Period were not multifunctional spaces unlike the ones in Anatolia. In both houses, the service spaces were demolished and rebuilt using up-to-date building materials. Material changes and additions which have been made according to today's needs caused differentiation in the three-dimensional composition and identity of the Sevilay Paşazade house. Since both houses are in use, they are in good structural condition (Table 1). 
Table 1. Analysis of Ali Kayımzade house and Sevilay Paşazade house. Source: Makbule Oktay, April 2019

\begin{tabular}{|c|c|c|}
\hline & Ali Kayımzade House & Sevilay Paşazade House \\
\hline Year & 1940 & 1927 \\
\hline Function & House & House \\
\hline Building plot - building relationship & $\begin{array}{l}\text { - } \quad \text { Parallel to the street } \\
\text { - } \quad \text { Defines the street } \\
\text { - } \quad \text { Located at the corner of the } \\
\text { plot } \\
\text { - } \quad \text { Garden at the back of the } \\
\text { house, access and garden on the } \\
\text { north }\end{array}$ & $\begin{array}{l}\text { - Parallel to the street } \\
\text { - } \\
\text { Defines the street } \\
\text { Located at the corner of the } \\
\text { plot } \\
\text { Garden at the back of the } \\
\text { house, access on the south }\end{array}$ \\
\hline Plan typology & $\begin{array}{ll} & \text { Interior sofa } \\
\text { - } & \text { Two-storey } \\
\end{array}$ & $\begin{array}{ll}\text { - } & \text { Interior sofa } \\
\text { - } & \text { Two-storey } \\
\end{array}$ \\
\hline Changes on the plan organisation & $\begin{array}{l}\text { Access to the kitchen and the } \\
\text { toilet and bathroom are } \\
\text { provided by a door from the } \\
\text { sofa }\end{array}$ & $\begin{array}{l}\text { The two-storey building is } \\
\text { divided into two different } \\
\text { houses } \\
\text { Necessary service spaces added } \\
\text { to each floor } \\
\text { - Access to the upper floor is } \\
\text { provided by building an outside } \\
\text { staircase and a terrace }\end{array}$ \\
\hline Spatial use & $\begin{array}{l}\text { The room, which used to be a } \\
\text { guest sitting room on the } \\
\text { ground floor, is now used as a } \\
\text { storage }\end{array}$ & 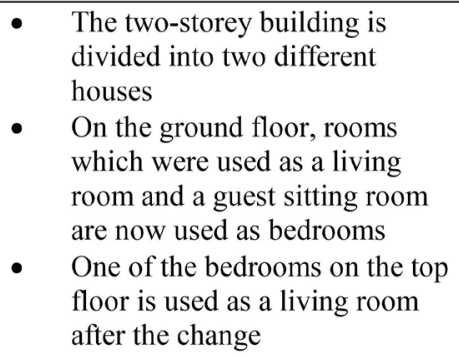 \\
\hline Façade features & $\begin{array}{l}\text { - } \\
\text { - } \\
\text { A projmetric } \\
\text { entrance door on the front } \\
\text { façade } \\
\text { - } \quad \text { Rectangular openings }\end{array}$ & $\begin{array}{l}\text { - Symmetric } \\
\text { A projecting bay above the } \\
\text { entrance door on the front } \\
\text { façade } \\
\text { - }\end{array}$ \\
\hline Changes on the façade organisation & $\begin{array}{l}\text { A door was opened to the east } \\
\text { façade of the living room on } \\
\text { the ground floor }\end{array}$ & $\begin{array}{l}\text { Ground floor window sizes } \\
\text { have been changed } \\
\text { Additions to the western (rear) } \\
\text { façade caused the change of the } \\
\text { original façade layout }\end{array}$ \\
\hline $\begin{array}{l}\text { Building materials and construction } \\
\text { technique }\end{array}$ & $\begin{array}{ll}\text { - } & \text { Mud brick } \\
\text { - } & \text { Wood } \\
\text { - } & \text { Bamboo mat } \\
\text { - } & \text { Marseille tiles } \\
\text { - } & \text { Traditional marble } \\
& \text { service on the additions; } \\
\text { - } & \text { Ceramics and tiles - on the } \\
\text { - } & \text { additions; service spaces } \\
& \text { Aluminium - door which was } \\
& \text { opened and on the additions } \\
\text { - } & \text { Load bearing } \\
\text { Reinforced concrete - service } \\
\text { spaces which were added }\end{array}$ & $\begin{array}{ll}\text { - } & \text { Mud brick } \\
\text { - } & \text { Bood } \\
\text { - } & \text { Traditional terracotta tile } \\
\text { - } & \text { Traditional marble } \\
\text { - } & \text { Marble } \\
\text { Parquet - change on the } \\
\text { material of the floor of the first } \\
\text { floor } \\
\text { - } \text { Brick - on the additions; } \\
\text { - } \quad \text { Cervice spaces } \\
\text { - } \quad \text { additions; service spaces } \\
\text { - } \quad \text { Load bearing } \\
\text { Reinforced concrete - service } \\
\text { spaces which were added }\end{array}$ \\
\hline
\end{tabular}

In general, these types of houses exhibit similarities with the rest of the traditional houses in Lefke regarding building plot-building relations, spatial organisation, building material, and construction techniques. The main difference between these houses and the rest is the projecting bay and the existence of the front garden which is found in some of the traditional houses. None of the two-storey houses with projecting bay have a front garden. 
Only one of them has a recessed entrance terrace. Besides, none of these houses are settled on inclined topography.

\section{Conclusion}

Thetraditionalhouses which reflect thetraces of theperiod in which they were built are the most important physical, tangible values that transmit the traces of socioeconomic structure, culture, and history of the societies to future generations. Therefore, these values should be studied, preserved and maintained. The declaration of protected site and achieving the Cittaslow status were important yet insufficient steps towards the preservation of architectural heritage values in Lefke. The existing problems can be listed as lack of interest and awareness, lack of investment, economic deficiency, and lack of users (including tourists). These are all linked together and any progress in one of them would trigger the rest. Preservation, conservation and rehabilitation of the historic fabric can be achieved with a holistic approach that includes; the regular inspection and punishment with fines for the wrong implementations which do not consider the existing rules and regulations in the protected area, education of the society to increase awareness on cultural heritage values, programmes to train the traditional building masters and craftsmen, encouraging and financially supporting people to conserve not only the traditional houses but all the traditional buildings and enable them to be used for public facilities where it is possible. The latter will also contribute to preventing the decay caused by the abandonment of the buildings. Offering new functions to the traditional buildings will also bring attraction and life to the historic town. Priority should be given to the utilization of the existing traditional buildings rather than injecting foreign images into the traditional pattern. Local authorities, non-governmental organisations, specialists from related professions, and society should work in collaboration to determine the necessary planning and conservation approaches. One of the initial steps should be the detailed documentation of the traditional buildings to be able to accurately conduct this type of comprehensive planning.

Having a rich historical and cultural heritage, Lefke has the opportunity to use these values for tourism purposes that could help the economic development of the region. Development can be achieved by preserving existing heritage values. Lefke has not yet reached the level where it could be in tourism. It is crucial to raise awareness of the importance and the necessity of the restoration and preservation of buildings in historic environments for cultural sustainability.

Traditional houses of Lefke are examples of Ottoman Architecture built in the British Period and represent a particular period. They are the symbols of the town and part of its identity that deserve attention. This study contributes to the literature of traditional Ottoman Architecture and traditional houses of Cyprus in general and traditional houses of Lefke in particular, mainly by documenting the architectural characteristics and spatial use through field study. It is believed that the information provided in this study will shed light on the understanding of specifically two-storey traditional houses with projecting bay of Lefke. This study can also contribute to future studies which might aim to investigate the typology of these houses, which is believed to be vital.

\section{References}

Ahunbay, Z. (2011). Tarihi çevre koruma ve restorasyon (6. Baskı). Yem Yayın.

Asatekin, G. (2005). Understanding traditional residential architecture in Anatolia. The Journal of Architecture, 10(4), 389 $-414$.

Bağışkan, T. (2018). Kıbrıs'ın geçmişine yolculuk. Kıbrıs Türk Yazarlar Birliği Yayını.

Bektaş, C. (2007). Turkish house. Bileşim Publisher.

Beratlı, N. (2002), Lefke sevgilim: Anılar. Işık Kitabevi.

Eldem, S. H. (1954). Turkish house plan types. İstanbul Technical University.

Feilden, B. M. (1994). Conservation of historic buildings. Butterworth Architecture.

Feridun, F. K. (1976). Lefke kasabasının sosyo-ekonomik yapısı ve göçler [Basılmamış bilim uzmanlığı tezi]. Hacettepe Üniversitesi, Nüfus Etütleri Enstitüsü.

Ferlison, İ. (1986). Adım adım Lefke ve yöresi [Basılmamış Mezuniyet Tezi]. Türk Öğretmen Koleji, Kıbrıs.

Gunnis, R. (1973). Historic Cyprus (3rd ed.) K. Rüstem \& Bro.

Güçhan, N. Ş. (2018). History and characteristics of construction techniques used in the traditional timber Ottoman houses. International Journal of Architectural Heritage, 12(1), 1 - 20.

Gürkan, H. M. (2008). Kıbrıs'ın sisli geçmişi: Toplu eserler - 6 . Galeri Kültür Yayınları.

Günay, R. (1999). Türk ev geleneği ve Safranbolu evleri. Yapı Endüstri Merkezi Yayınları.

Hill, G. (2016). Kıbrıs tarihi: Osmanlı ve İngiliz idaresi dönemi 1571-1948. Türkiye İş Bankası Kültür Yayınları.

Keshishian, K. K. (1993). Romantic Cyprus: Everybody's guide (17th ed.). Printco.

Kırşan, Ç. (1998). Lefke'nin kent dokusu ve evleri üzerine bir çözümleme. Kıbrıs Araştırmaları Merkezi Yayınları, Gazimağusa, Doğu Akdeniz Üniversitesi, IV, 487-506.

Kuban, D. (2000). Tarihi çevre korumanın mimarlık boyutu: Kuram ve uygulama. Yapı-endüstri Merkezi Yayınları.

Kuban, D. (2017). Türk ahşap konut mimarisi: 17. - 19. yüzyıllar (2. Basım). Türkiye İş Bankası Kültür Yayınları.

Kuşçu, H. \& Kuşçu, O. (1998). The Mansion of Hasan Kurtoğlu in Amasya. S. Ireland \& W. Bechhoefer (Eds.), The Ottoman house, papers of the Amasya symposium 24-27 September 1996 (pp.95-102). London, British Institute at Ankara. http:// www.jstor.org/stable/10.18866/j.ctt1pc5grs.23

Küçükerman Ö. (1996). Turkish house: In search of spatial identity (5th ed.). Promat Basım Yayın. 
[Map of Lefke] [map]. (Unknown). Municipality of Lefke Archive.

Oktay, G. (2000a, Nisan). Lefke yöresinde eski eserlere bir bakış. Lefke Gazetesi, 3, 15.

Oktay, G. (2000b, Mart). Lefke yöresinde eski eserlere bir bakış. Lefke Gazetesi, 2, 26.

Oktay, M. \& Tomak, Ö. G. (2019). Geleneksel mimariye bakış: Geleneksel Lefke evlerine bir örnek. O. Gemikonaklı, M. Oktay \& T. Oktay (Eds.), 1. Lefke Kent Sempozyumu, Sempozyum bildiriler kitabı-1 (ss.298-313). TipografART Basım Yayın, Lefke Belediyesi Yayınları-1.

O.S.A. (Cartographer). (1952). Mavrovouni Village [map]. 1:1,000. Drawing Number: A-3111-3, 30.12.1952. Xero, Cyprus: Cyprus Mines Corporation General Survey.

Öztek, E. (1989). Lefke kent merkezi düzenleme projesi. KKTC Şehir Planlama Dairesi.

PRIO Cyprus Centre. (n.d.). International displacement in Cyprus: Mapping the consequences of civil and military strife. Retrieved April 15, 2019, from http://www.prio-cyprus-displacement.net

Pulhan, H. \& Numan, İ. (2005). The transitional space in the traditional urban settlement of Cyprus. Journal of Architectural and Planning Research, 22(2), 160-178.

Pulhan, H. \& Numan, i. (2006). The traditional urban house in Cyprus as material expression of cultural transformation.
Journal of Design History, 19(2), 105-119.

Rapoport, A. (1969). House form and culture. Prentice-Hall. TRNC Official Gazette. (1999, July 3) (81), 693 - 695.

TRNC Official Gazette. (2014, February14), (34), 127, 278-281.

Tuztaşı, U. \& Aşkun, İ. Y. (2013). Functional explanations regarding the common qualities of the "Ottoman House" and the "Anatolian House" within the context of the idealization of the "Turkish House". Bilig, 66, 273-296.

Türeli, İ. (2014). Heritagisation of the "Ottoman/Turkish House" in the 1970s: Istanbul-based actors, associations and their networks. European Journal of Turkish Studies, 19. http:// journals.openedition.org/ejts/5008

International Council on Monuments and Sites. (2020, October 28).

https://www.icomos.org/images/DOCUMENTS/Charters/ vernacular_e.pdf

Yıldız, N. (1998). Ottoman Houses in Cyprus. S. Ireland \& W. Bechhoefer (Eds.), The Ottoman house, papers of the Amasya symposium 24-27 September 1996 (pp.79-88). London, British Institute at Ankara. http://www.jstor.org/stable/10.18866/j. ctt1pc5grs

Yükselen, Ç. K. (1999). Lefke'nin geleneksel dokusunun sürekliliğini sağlayan etkenler ve CMC gerçeği. Halkbilimi Has-Der, 47, 48-57. 